\title{
Additions to the Genus Arthrinium (Apiosporaceae) From Bamboos in China
}

\author{
Yao Feng ${ }^{1,2}$, Jian-Kui (Jack) Liu ${ }^{3 *}$, Chuan-Gen Lin', Ya-Ya Chen ${ }^{2,5}$, Mei-Mei Xiang ${ }^{6}$ and \\ Zuo-Yi Liu ${ }^{2 *}$
}

${ }^{1}$ College of Agriculture, Guizhou University, Guiyang, China, ${ }^{2}$ Guizhou Key Laboratory of Agricultural Biotechnology, Guizhou Academy of Agricultural Sciences, Guiyang, China, ${ }^{3}$ School of Life Sciences and Technology, University of Electronic Science and Technology, Chengdu, China, ${ }^{4}$ Centre of Excellence in Fungal Research, Mae Fah Luang University, Chiang Rai, Thailand, ${ }^{5}$ Institute of Crop Germplasm Resources, Guizhou Academy of Agricultural Sciences, Guiyang, China,

${ }^{6}$ Innovative Institute for Plant Health, Zhongkai University of Agriculture and Engineering, Guangzhou, China

\section{OPEN ACCESS}

Edited by:

Peter Edward Mortimer, Kunming Institute of Botany, Chinese Academy of Sciences, China

Reviewed by:

Indunil Senanayake, Shenzhen University, China

ZongLong Luo,

Dali University, China

*Correspondence:

Jian-Kui (Jack) Liu liujiankui@uestc.edu.cn

Zuo-Yi Liu

gzliuzuoyi@163.com

Specialty section:

This article was submitted to

Evolutionary and Genomic

Microbiology,

a section of the journal

Frontiers in Microbiology

Received: 30 January 2021

Accepted: 10 March 2021

Published: 07 April 2021

Citation:

Feng Y, Liu J-K, Lin C-G,

Chen $Y-Y$, Xiang M-M and Liu Z-Y

(2021) Additions to the Genus Arthrinium (Apiosporaceae) From

Bamboos in China.

Front. Microbiol. 12:661281. doi: 10.3389/fmicb.2021.661281
Arthrinium has a widespread distribution occurring in various substrates (e.g., air, soil debris, plants, lichens, marine algae and even human tissues). It is characterized by the basauxic conidiogenesis in the asexual morph, with apiospores in the sexual morph. In this study, seventeen isolates of Arthrinium were collected in China. Based on their morphology and phylogenetic characterization, four new species (A. biseriale, A. cyclobalanopsidis, A. gelatinosum, and A. septatum) are described and seven known species (A. arundinis, A. garethjonesii, A. guizhouense, A. hydei, A. neosubglobosa, $A$. phyllostachium and $A$. psedoparenchymaticum) are identified, of which the sexual morph of three species (A. guizhouense, A. phyllostachium and A. psedoparenchymaticum) and asexual morph of $A$. garethjonesii are reported for the first time. The detailed descriptions, illustrations and comparisons with related taxa of these new collections are provided. Phylogenetic analyses of combined ITS, LSU, TUB2, and TEF sequence data support their placements in the genus Arthrinium and justify the new species establishments and identifications of known species.

Keywords: 4 new taxa, asexual-sexual morphs, multi-genes, phylogeny, taxonomy

\section{INTRODUCTION}

The genus Arthrinium Kunze belongs to the family Apiosporaceae, which was introduced by Hyde et al. (1998) and typified by the genus Apiospora (Ellis, 1971; Seifert et al., 2011; Hyde et al., 2020). Arthrinium is the largest genus within Apiosporaceae and it has a widespread distribution on variety of hosts, 77 species have been recorded by Species Fungrom (March, 2021). Classification of Arthrinium was primarily based on conidial shape, conidiophores, sterile cells, and the presence of setae. Some morphologically different taxa (genera) grouped with Arthrinium when use the molecular data (Crous and Groenewald, 2013). Thus, those characteristics could be not fully inferred about the phylogenetic relationships for Arthrinium (Crous and Groenewald, 2013; Wang et al., 2018; Pintos et al., 2019). Except for being reported as saprobes (Agut and Calvo, 2004; Crous and Groenewald, 2013; Dai et al., 2016, 2017; Jiang et al., 2018; Wang et al., 2018; Jiang et al., 2019, 2020; Luo et al., 2019; Pintos et al., 2019; Yan et al., 2019; Mapook et al., 2020; Senanayake et al., 2020a; Tang et al., 2020), the species of Arthrinium also includes phytopathogenic fungi, for instance, A. arundinis causing brown culm 
streak of Phyllostachys praecox, A. phaeospermum causing culm rot on Phyllostachys viridis and cutaneous infections of humans (Rai, 1989; Zhao et al., 1990; Martínez-Cano et al., 1992; Mavragani et al., 2007; Crous and Groenewald, 2013; Li et al., 2016; Wang et al., 2018).

we are carrying out the survey of fungal diversity in Karst formations of the Asian region, and many new taxa are described in last few years (Li et al., 2016; Chen et al., 2017, 2020; Zhang et al., 2017, 2019; Feng et al., 2019; Liu et al., 2019; Dissanayake et al., 2020b). In this study, seventeen Arthrinium-like were collected in Guizhou and Guangdong province, China and can be recognized as eleven Arthrinium species based on morphological characters and phylogeny inferred from the multi-gene sequences data (ITS, LSU, TUB2, and TEF) analyses, which four new species (A. biseriale, A. cyclobalanopsidis, A. gelatinosum, and $A$. septatum) and seven known species (A. arundinis, A. garethjonesii, A. guizhouense, A. hydei, A. neosubglobosa, A. phyllostachium and A. psedoparenchymaticum) are introduced and identified, respectively. The aim of this study is to describe these new taxa with detailed descriptions and illustrations, and also provide their phylogenetic relationships within Arthrinium based on multi-gene analysis.

\section{MATERIALS AND METHODS}

\section{Sample Collection, Morphological Studies and Isolation}

Samples were collected from Guizhou and Guangdong Province in China. Fungal fruiting bodies were examined by using stereomicroscope (Motic SMZ 168). Free hand sections of fungal structures were mounted in water for microscopic studies and photomicrography. Images were taken by using a Nikon ECLIPSE Ni compound microscope fitted with a Canon EOS $70 \mathrm{D}$ digital camera. All measurements were taken by using Tarosoft Image Frame Work software (IFW) (Liu et al., 2010), and photo plates were processed with Adobe Photoshop CS6 software (Adobe Systems, United States).

The single spore isolation followed the method described in Senanayake et al. (2020b). Parts of morphological descriptions were based on sporulated cultures on WA (Water Agar) at room temperature (ca. $25^{\circ} \mathrm{C}$ ). Type specimens were deposited in the herbarium of Cryptogams Kunming Institute of Botany Academia Sinica (HKAS), Kunming, China and Guizhou Academy of Agriculture sciences Herbarium (GZAAS). Pure cultures were deposited in China General Microbiological Culture Collection Center (CGMCC) and Guizhou Culture Collection (GZCC). Faces of Fungi ${ }^{1}$ number is obtained as described in the paper by Jayasiri et al. (2015), and the new taxa are registered in Index Fungorum (2021).

\section{DNA Extraction, PCR Amplification and Sequencing}

Fungal mycelia were scraped from the pure culture which were growing on PDA (Potato Dextrose Agar) for one week at $25^{\circ} \mathrm{C}$ in

${ }^{1}$ http://www.facesoffungi.org/ dark. DNA was extracted by using Ezup Column Fungi Genomic DNA Purification Kit (Sangon Biotech, China) from fresh fungal mycelia, but some were extracted directly from fruiting bodies by using Forensic DNA Kit (Omega Bio-Tek, China). Four gene regions, large subunit rDNA (LSU), internal transcribed spacer (ITS), beta-tubulin (TUB2) and the translation elongation factor 1-alpha (TEF) gene were amplified by the primer pairs LR0R and LR5 (Vilgalys and Hester, 1990), ITS5 and ITS4, T1 (O’Donnell and Cigelnik, 1997) and Bt2b (Glass and Donaldson, 1995), EF1728F and EF-2 (O’Donnell et al., 1998; Carbone and Kohn, 1999), respectively. Polymerase chain reaction (PCR) was carried out in $25 \mu \mathrm{L}$ reaction volume containing $12.5 \mu \mathrm{L} 2 \times$ PCR Master Mix (Sangon Biotech, China), $9.5 \mu \mathrm{L}$ ddH $_{2} \mathrm{O}, 1 \mu \mathrm{L}$ of each primer and $1 \mu \mathrm{L}$ DNA template. The annealing temperatures were adjusted to $56^{\circ} \mathrm{C}$ for ITS, LSU and TUB2, and $55^{\circ} \mathrm{C}$ for TEF. PCR products were sent to sequence at Sangon Biotech Co., Ltd., China. The PCR products were examined using 1.2\% agarose electrophoresis gel stained with ethidium bromide. PCR products were purified and sequenced by Sangon Biotech (Shanghai) Co., Ltd., China. New generated nucleotide sequences were submitted in GenBank (Table 1).

\section{Phylogenetic Analyses}

Phylogenetic analyses were performed based on ITS, LSU, TUB2 and TEF sequence data. The related strains of Apiosporaceae (Table 1) used for analysis were referred to BLAST ${ }^{2}$ results and relevant publications (Wang et al., 2018; Jiang et al., 2019, 2020; Pintos et al., 2019; Tang et al., 2020). Sequences were obtained from GenBank and aligned using MAFFT v. 7 (Katoh and Standley, 2013). Manual adjustment was also performed when it is necessary by using BioEdit v. 7.0 (Hall, 1999). The alignment of sequences data used in analyses is deposited in TreeBASE under the accession number S27728. The analyses of maximum parsimony (MP), maximum likelihood (ML) and Bayesian inference (BI) were carried out as detailed in Dissanayake et al. (2020a) and programs used including PAUP v.4.0b 10 (Hillis and Bull, 1993; Swofford, 2002), raxmlGUI v. 1.3 (Silvestro and Michalak, 2012), and MrBayes v3.1.2 (Rannala and Yang, 1996; Huelsenbeck and Ronquist, 2001; Zhaxybayeva and Gogarten, 2002; Nylander, 2004). Trees were visualized with FigTree v1.4.2 (Rambaut, 2012) and the layout was edited using Adobe Illustrator CS6.

\section{RESULTS}

\section{Phylogeny}

To determine the phylogenetic placement of the new collections in this study, the combined ITS, LSU, TUB2 and TEF data set comprised 119 taxa with Seiridium phylicae (CPC 19962 and CPC 19965) as the outgroup taxa. The concatenated alignment comprises 2,770 characters (ITS: 1-635; LSU: 636-1,454; TUB2: 1,455-2,300; TEF: 2,301-2,770) including gaps, of which 1,361 characters were constant, and 1,279 characters are parsimony informative and 130 are parsimony uninformative. Maximum

\footnotetext{
${ }^{2}$ https://blast.ncbi.nlm.nih.gov/Blast.cgi
} 
TABLE 1 | GenBank accession numbers of species included in the phylogenetic study.

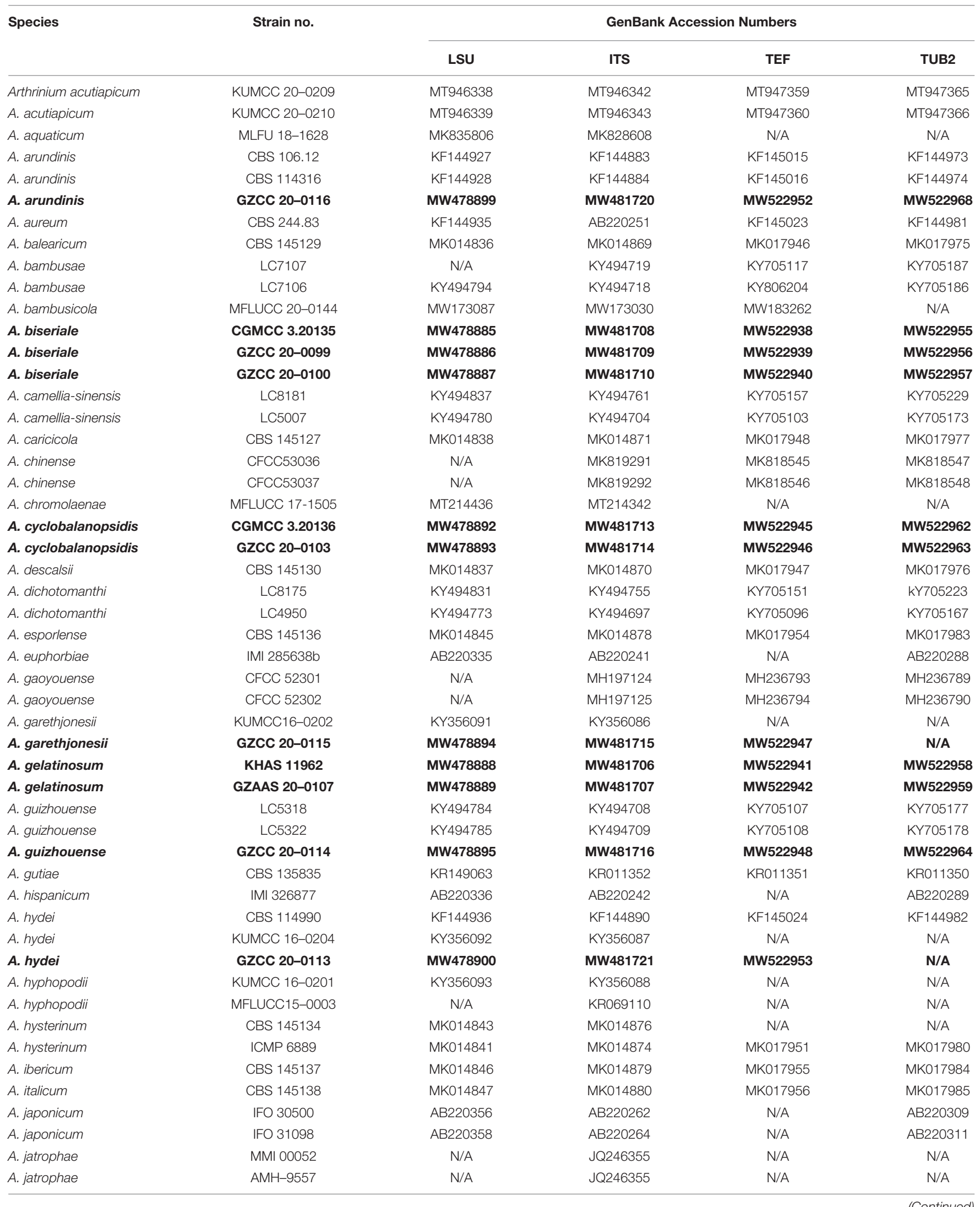


TABLE 1 | Continued

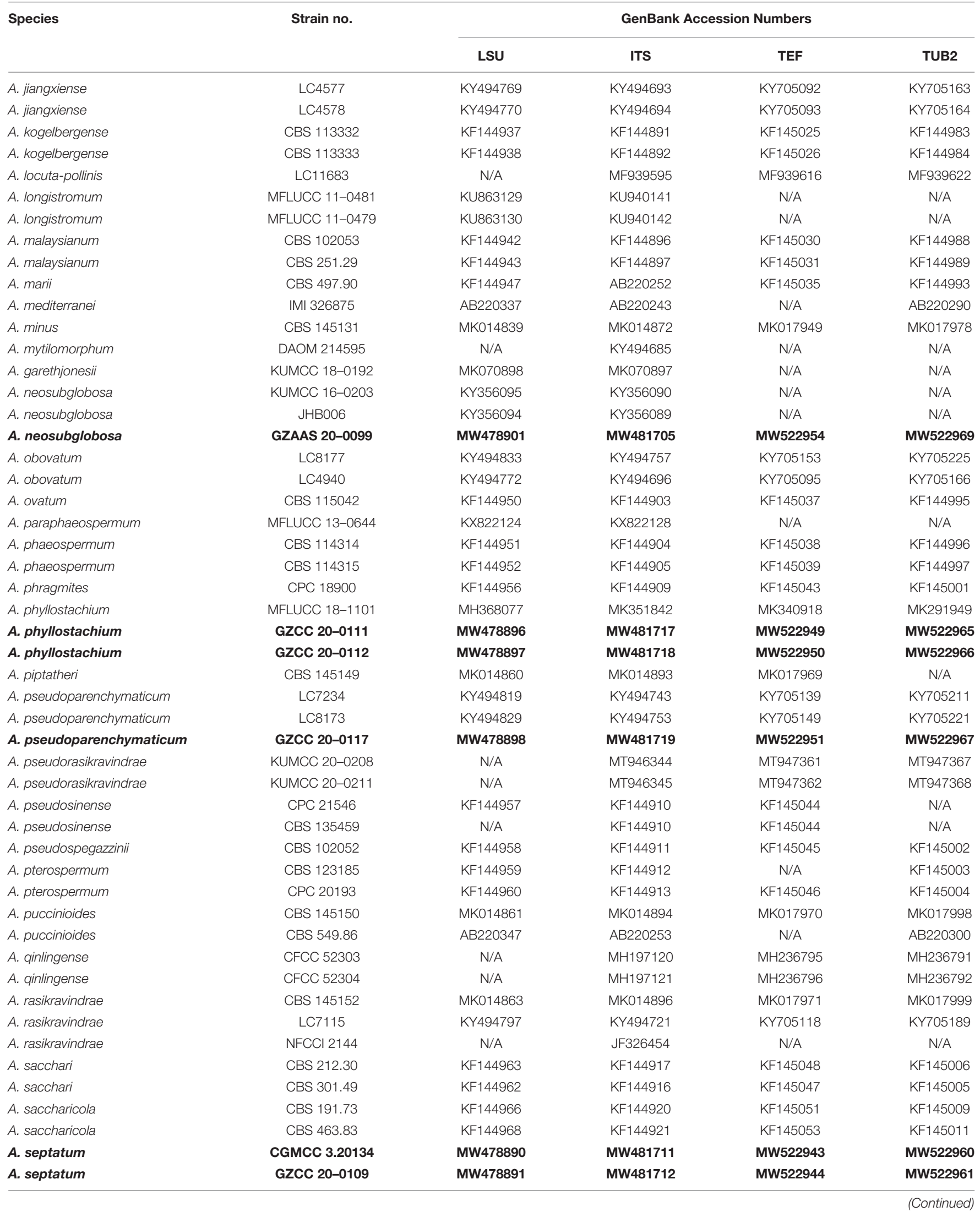


TABLE 1 | Continued

\begin{tabular}{|c|c|c|c|c|c|}
\hline \multirow[t]{2}{*}{ Species } & \multirow[t]{2}{*}{ Strain no. } & \multicolumn{4}{|c|}{ GenBank Accession Numbers } \\
\hline & & LSU & ITS & TEF & TUB2 \\
\hline A. serenense & IMI 326869 & AB220344 & AB220250 & $\mathrm{N} / \mathrm{A}$ & AB220297 \\
\hline A. setostromum & KUMCC 19-0217 & MN528011 & MN528012 & MN527357 & $\mathrm{N} / \mathrm{A}$ \\
\hline A. sporophleum & CBS 145154 & MK014865 & MK014898 & MK017973 & MK018001 \\
\hline A. subglobosum & MFLUCC 11-0397 & KR069113 & KR069112 & $\mathrm{N} / \mathrm{A}$ & $\mathrm{N} / \mathrm{A}$ \\
\hline A. subroseum & LC7292 & KY494828 & KY494752 & KY705148 & KY705220 \\
\hline A. thailandicum & MFLUCC 15-0199 & KX986111 & KU940146 & $\mathrm{N} / \mathrm{A}$ & $\mathrm{N} / \mathrm{A}$ \\
\hline A. thailandicum & MFLUCC 15-0202 & KU863133 & KU940145 & $\mathrm{N} / \mathrm{A}$ & $\mathrm{N} / \mathrm{A}$ \\
\hline A. trachycarpum & CFCC 53038 & $\mathrm{~N} / \mathrm{A}$ & MK301098 & MK303396 & MK303394 \\
\hline A. trachycarpum & CFCC 53039 & $\mathrm{~N} / \mathrm{A}$ & MK301099 & MK303397 & MK303395 \\
\hline A. urticae & IMI 326344 & AB220339 & AB220245 & $\mathrm{N} / \mathrm{A}$ & $\mathrm{N} / \mathrm{A}$ \\
\hline A. vietnamese & IMI 99670 & KX986111 & KX986096 & $\mathrm{N} / \mathrm{A}$ & KY019466 \\
\hline A. xenocordella & CBS478.86 & KF144970 & KF144925 & KF145055 & KF145013 \\
\hline A. xenocordella & CBS 595.66 & KF144971 & KF144926 & $\mathrm{N} / \mathrm{A}$ & $\mathrm{N} / \mathrm{A}$ \\
\hline A. yunnanum & DDQ 00281 & KU863136 & KU940148 & $\mathrm{N} / \mathrm{A}$ & $\mathrm{N} / \mathrm{A}$ \\
\hline A. yunnanum & MFLU 15-0002 & $\mathrm{N} / \mathrm{A}$ & KU940147 & $\mathrm{N} / \mathrm{A}$ & $\mathrm{N} / \mathrm{A}$ \\
\hline Seiridium phylicae & CPC 19962 & NG 042759 & LT853092 & LT853189 & LT853239 \\
\hline Seiridium phylicae & CPC 19965 & KC005809 & LT853093 & LT853190 & LT853240 \\
\hline
\end{tabular}

The newly generated sequence is shown in bold. AMH: Ajrekar Mycological herbarium, Pune, Maharashtra, India; CBS: Westerdijk Fungal Biodiversity Institute, Utrecht, Netherlands; CFCC: China Forestry Culture Collection Center, Beijing, China; CGMCC: China General Microbiological Culture Collection Center, Beijing, China; CPC: Culture collection of Pedro Crous, housed at the Westerdijk Fungal Biodiversity Institute; DAOM: Canadian Collection of Fungal Cultures, Ottawa, Canada; DDQ: D. Q. Dai;

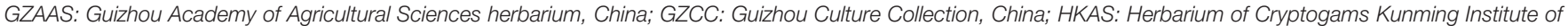

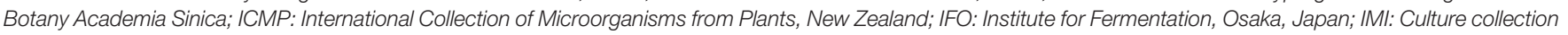

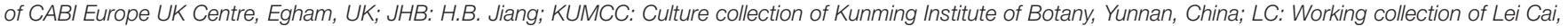
housed at CAS, China; MFLUCC: Mae Fah Luang University Culture Collection, Chiang Rai, Thailand; NFCCl: National Fungal Culture Collection of India.

likelihood, maximum parsimony and Bayesian analyses were performed, respectively, and presented consistent topologies. The best scoring RAxML tree (Figure 1) is obtained with a final likelihood value of -27544.434044 . Estimated base frequencies were as follows: $\mathrm{A}=0.236829, \mathrm{C}=0.253015, \mathrm{G}=0.251523$, $\mathrm{T}=0.258634$; substitution rates $\mathrm{AC}=1.154254, \mathrm{AG}=2.738844$, $\mathrm{AT}=1.073582, \mathrm{CG}=0.896658, \mathrm{CT}=4.134885, \mathrm{GT}=1.000000$; The gamma distribution shape parameter alpha is equal to 0.332641 and the Tree-Length equal to 3.795226 .

Phylogenetic analyses showed that our newly collected seventeen taxa clustered into eleven clades and can be recognized as seven known species (Arthrinium arundinis, A. garethjonesii, A. guizhouense, A. hydei, A. neosubglobosa, A. phyllostachium, A. psedoparenchymaticum) and four new species (A. biseriale, A. cyclobalanopsidis, A. gelatinosum, A. septatum) (Figure 1).

\section{Taxonomy}

\section{Arthrinium biseriale Y. Feng and Z.Y. Liu, sp. nov. Figure 2}

Index Fungorum number: IF558136

Facesoffungi number: FoF 09569

Etymology: The epithet refers to the ascospores are arranged in two rows in the ascus.

Holotype: HKAS 111961

Saprobic on dead bamboo culms, forming black, lenticular spots on the host surface, with stromata breaking through raised cracks with black center, and merge with each other with age, forming an erumpent black mass visible at the naked eye. Sexual morph: Stromata scattered to gregarious, immersed to erumpent, later becoming superficial, dark brown to black, fusiform, forming a slit-like opening at the apex, multi-loculate, membranous, with a periphysate ostiole. Ascomata $122-153 \mu \mathrm{m}$ high, 138-207 $\mu \mathrm{m}$ diam, arranged in rows, dark brown to black. Peridium 11-19 $\mu \mathrm{m}$ wide, composed of several layers of dark brown to hyaline cells of textura angularis. Hamathecium 3$4 \mu \mathrm{m}$ wide, comprising dense, hyaline, septa paraphyses. Asci 84-116 $\mu \mathrm{m} \times 18-25 \mu \mathrm{m}(\bar{x}=97 \mu \mathrm{m} \times 21 \mu \mathrm{m}, n=20), 8-$ spored, unitunicate, clavate, apically rounded, with an indistinct pedicel. Ascospores $22-28 \mu \mathrm{m} \times 7-11 \mu \mathrm{m}(\bar{x}=25 \mu \mathrm{m} \times 9$ $\mu \mathrm{m}, n=30$ ), biseriate, fusiform, curved at the bottom, obtuse at both ends, slightly wider in the middle, hyaline, 1-septate, constricted at the septum, mostly curved at the lower cell, rarely straight, with a large upper cell and a small lower cell, smoothwalled. The lower cell has 1-guttulate, the upper cell has 1-3 big guttulate in the middle surrounded by multiple small guttulate with a shallow 4-7 $\mu \mathrm{m}$ thick gelatinous sheath in the early. Growing to a later stage, the guttulate filled the entire spore, and the gelatinous sheath dissolves easily. Asexual morph: On WA, Hyphae 2.5-6.0 $\mu \mathrm{m}$ diam, hyaline, branched, septate, some curled in a ring structure. Conidiophores 12.0-44.0 $\mu \mathrm{m} \times 2.5-5.0 \mu \mathrm{m}(\bar{x}=20.0 \mu \mathrm{m} \times 3.5 \mu \mathrm{m}, n=20)$, straight or flexuous, smooth, thin-walled, unbranched, hyaline to pale brown, cylindrical, cyathiform, having transverse septa, often reduced to conidiogenous cells. Conidiogenous cells 5.0-22.0 $\mu \mathrm{m} \times 2.5-5.0 \mu \mathrm{m}(\bar{x}=10.0 \mu \mathrm{m} \times 3.5 \mu \mathrm{m}, n=20)$, integrated, hyaline to pale brown, doliiform to ampulliform, or lageniform. 
Conidia 7-9 $\mu \mathrm{m}$ long $(n=30)$, brown, smooth in surface view, and $7-11 \mu \mathrm{m}$ long $(n=30)$, lenticular, with a paler equatorial slit in side view, globose to ellipsoid with many guttules.

\section{Culture characters}

Ascospores germinated on WA within $24 \mathrm{~h}$ and germ tubes produced from middle and lower end. Colonies fast

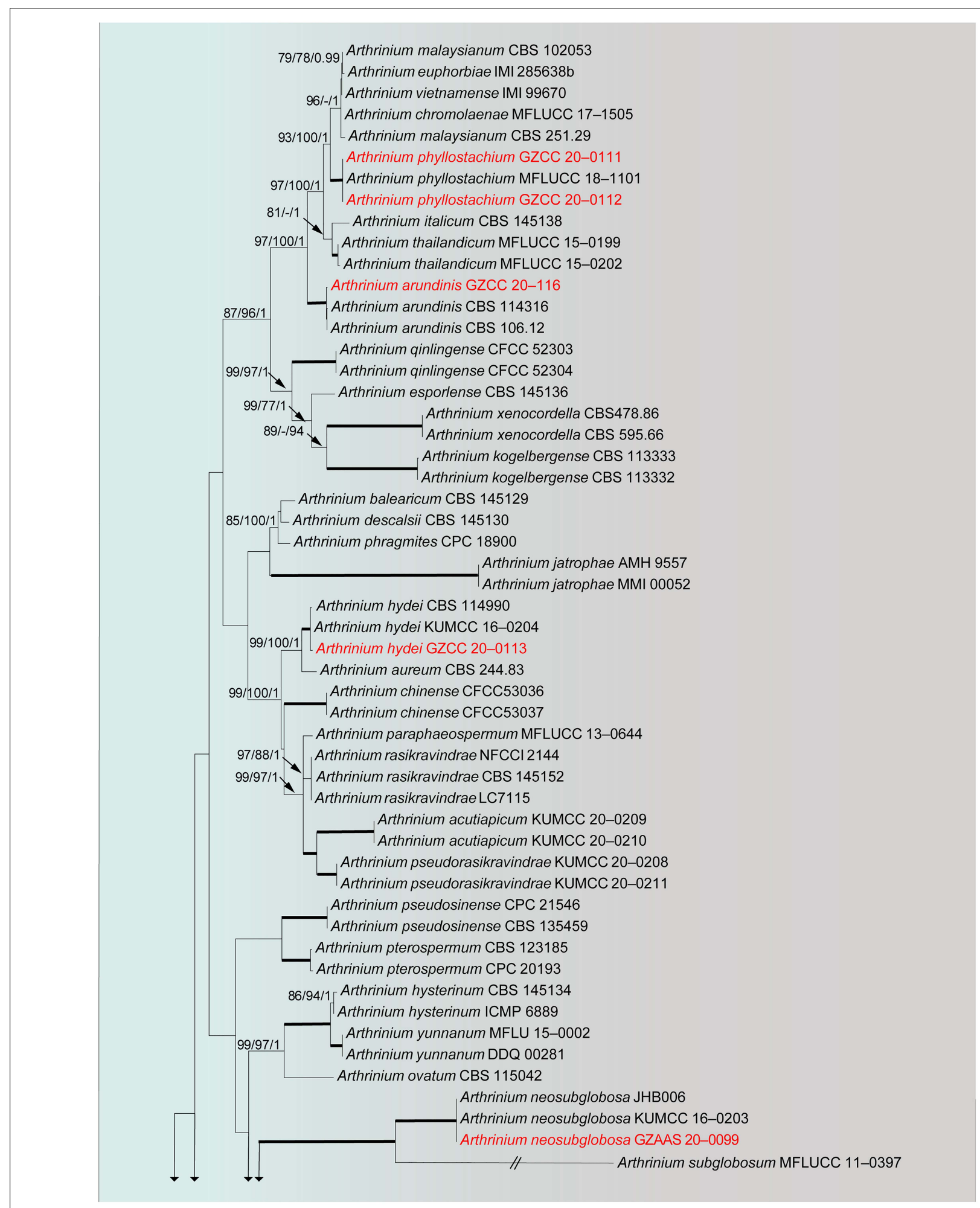

FIGURE 1 | Continued 


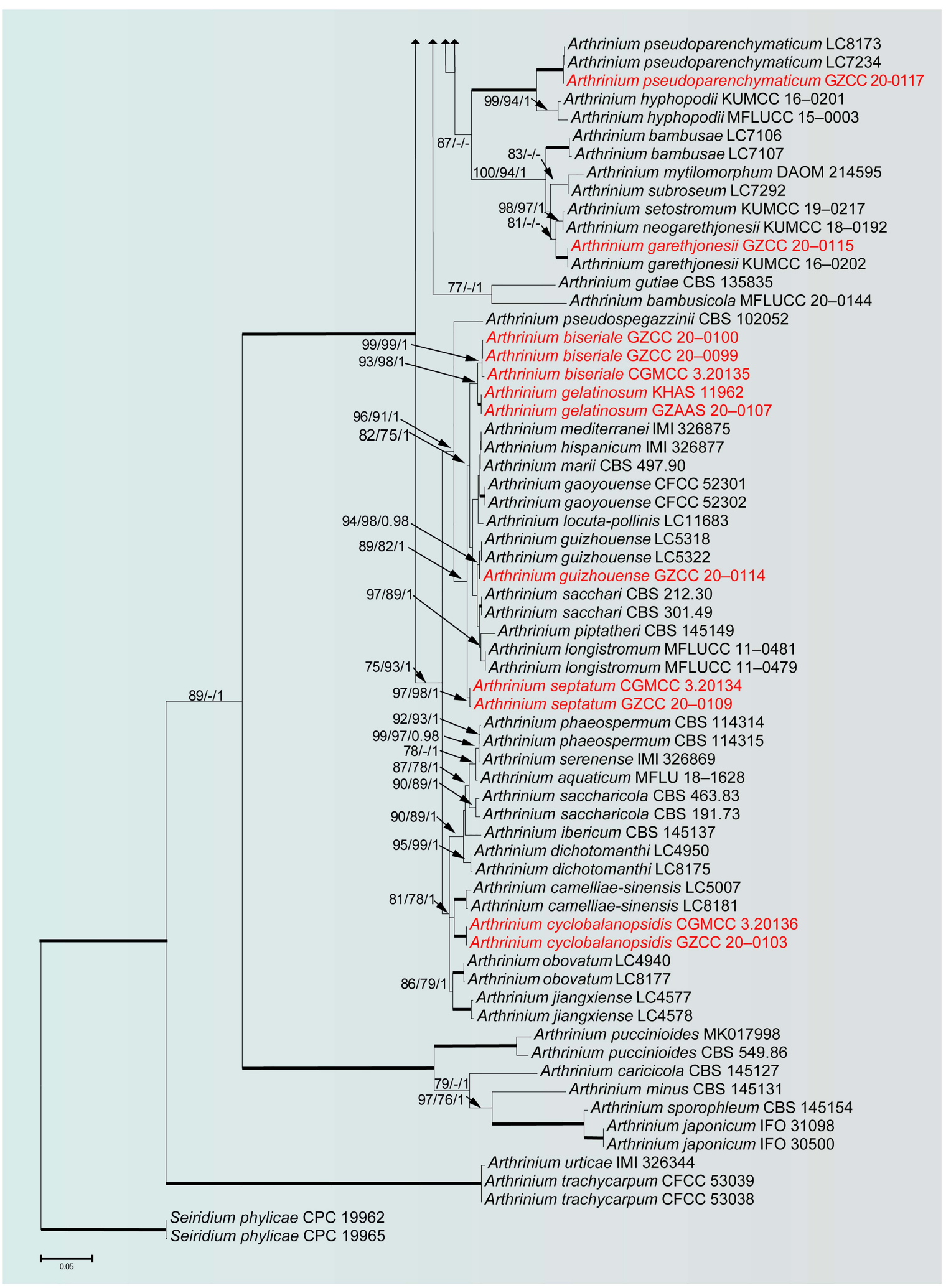

FIGURE 1 | RAXML tree of representatives based on a combined dataset of ITS, LSU, TUB2 and TEF sequences. Bootstrap support values for ML, MP ( $\geq 75 \%)$ and Bayesian $(\geq 0.95)$ are given at the nodes (ML/MP/BI). Branches with ML, MP and BI equal 100, 100 and 1 are in bold. The tree is rooted with Seiridium phylicae (CPC 19962 and CPC 19965). New strains are shown in red. 

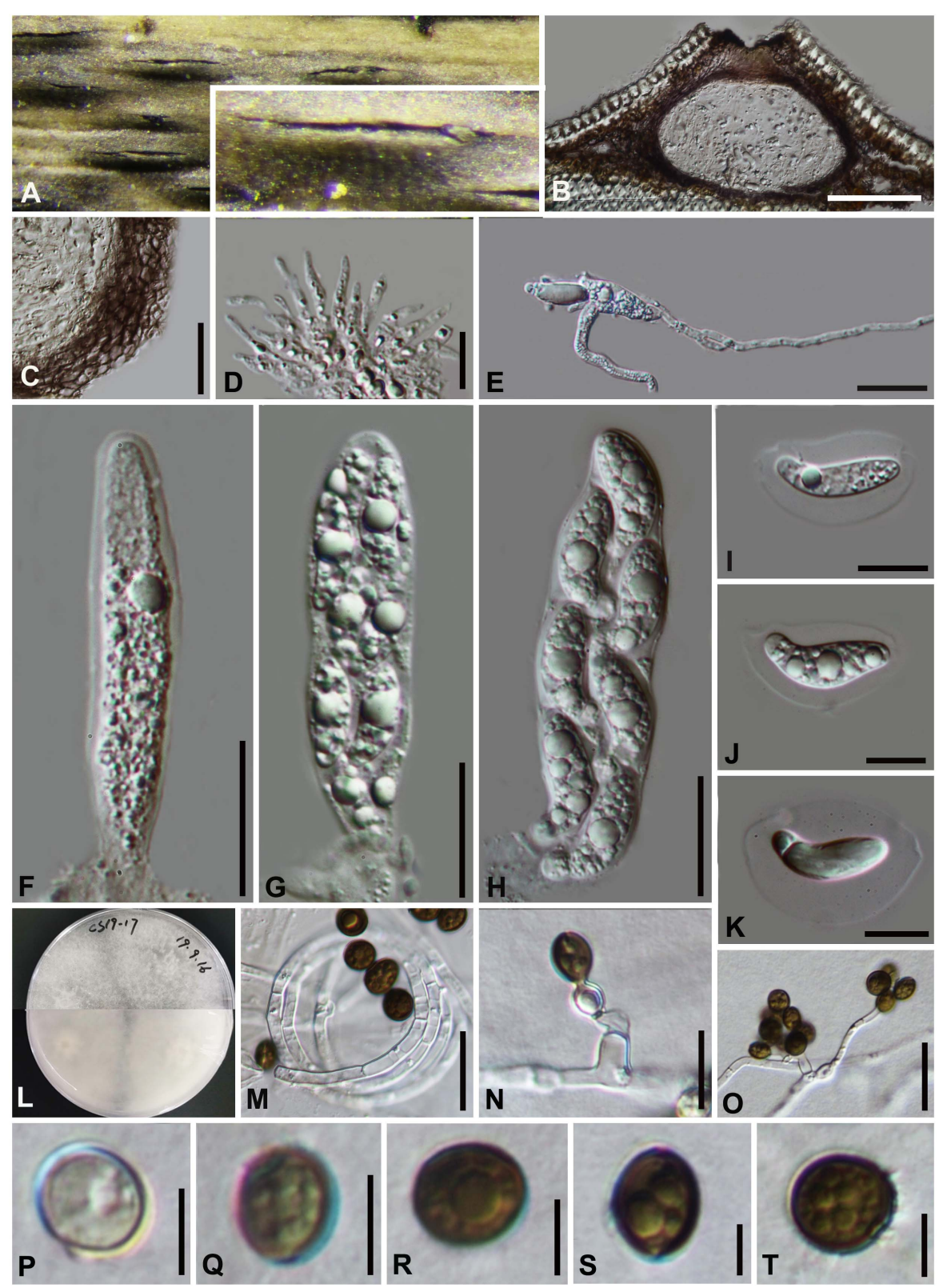

FIGURE 2 | Arthrinium biseriale (HKAS 111961, holotype). (A) Appearance of stromata on bamboo host. (B) Vertical section of stroma. (C) Peridium. (D) Paraphyses. (E) Germinating ascospore. (F-H) Asci. (I-K) Ascospore. (L) Culture. (M) Hyphae. (N,O) Conidiophore and conidiogenous cells. (P-T) Conidia. Scale bars: (B) $=50 \mu \mathrm{m} . \mathbf{( C )}=20 \mu \mathrm{m} .(\mathbf{D})=10 \mu \mathrm{m} . \mathbf{( E - H )}=20 \mu \mathrm{m} . \mathbf{( I - K )}=10 \mu \mathrm{m} . \mathbf{( M )}=20 \mu \mathrm{m} .(\mathbf{N})=10 \mu \mathrm{m} .(\mathbf{O})=20 \mu \mathrm{m} . \mathbf{( P - T )}=5 \mu \mathrm{m}$.

grown on $\mathrm{PDA}$ at $25^{\circ} \mathrm{C}$, reached $7 \mathrm{~cm}$ in 7 days at $25^{\circ} \mathrm{C}$. Colonies evenly tiled, with a large number of aerial hyphae, white, velvety, thin, gray-white on the reverse side and dirty white in the center.

\section{Materials examined}

China, Guizhou Province, Chishui City, Zhuhai National Forest Park, on dead culms of bamboo, 10 July 2019, Yao Feng, CS1917 (HKAS 111961, holotype; GZAAS 20-0102, isotype), ex-type living cultures, CGMCC 3.20135 = GZCC 20-0101. Ibid., on dead base of the bamboo stem, 10 July 2019, Yao Feng, CS 19-25
(GZAAS 20-0101), living culture, GZCC 20-0100. Ibid., on dead branch of bamboo, 11 July 2019, Ya-Ya Chen, CS 013 (GZAAS 20-0100), living culture, GZCC 20-099.

\section{Notes}

Three strains representing Arthrinium biseriale clustered in a well-supported clade which are closely related to A. gelatinosum, but phylogenetically distinct and can be recognized as two different species (99\% sequence similarity in ITS; $99 \%$ in TEF; 98\% in TUB2). Morphologically, Arthrinium biseriale has smaller stromata $(122-153 \mu \mathrm{m} \times 138-207 \mu \mathrm{m}$ vs. $144-199$ 


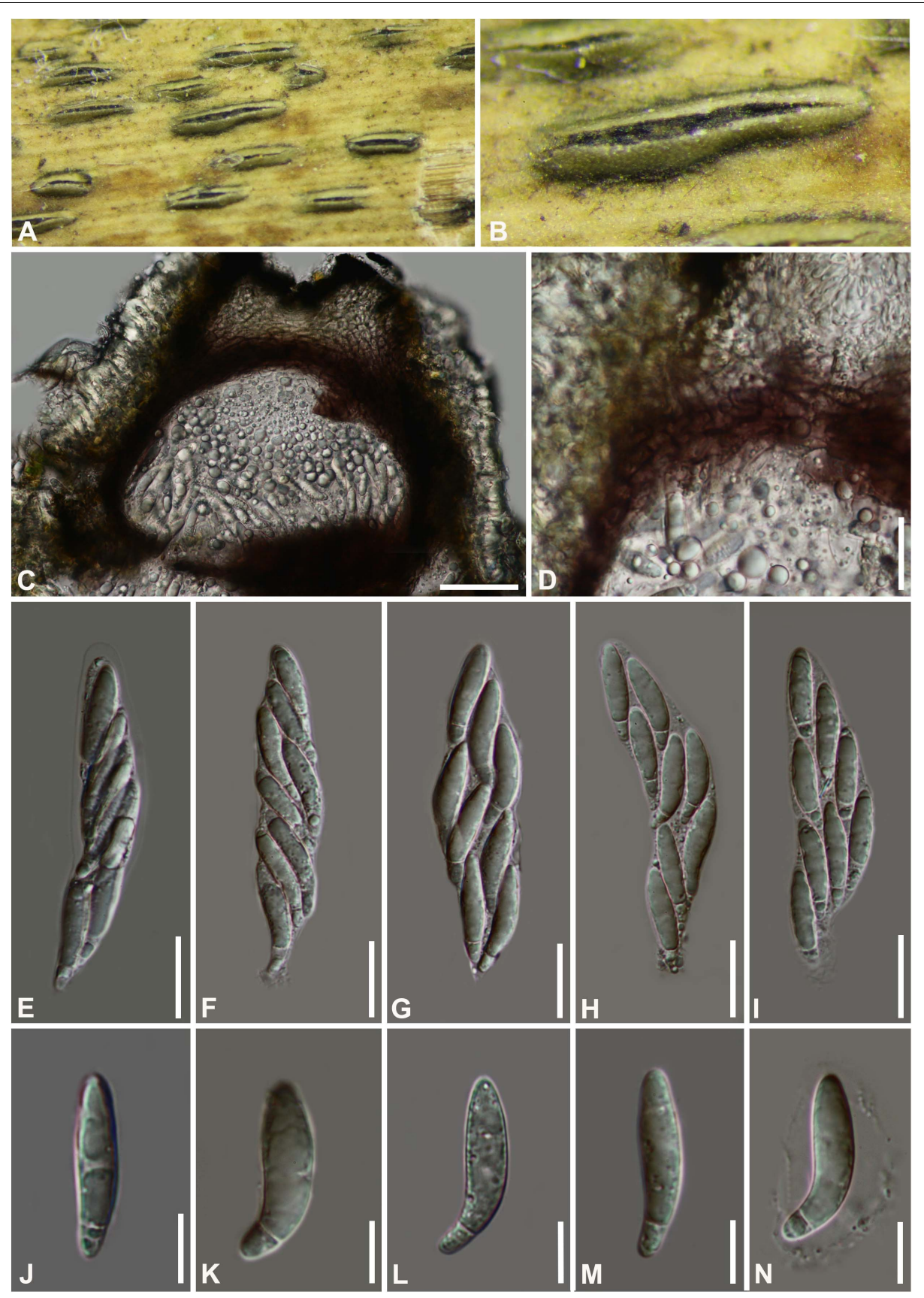

FIGURE 3 | Arthrinium gelatinosum (HKAS 111962, holotype). (A,B) Appearance of stromata on bamboo host. (C) Vertical section of stroma. (D) Peridium. (E-I) Asci. (J-N) Ascospore. Scale bars: (C) $=50 \mu \mathrm{m}$. (D-I) $=20 \mu \mathrm{m}$. (J-N) $=10 \mu \mathrm{m}$.

$\mu \mathrm{m} \times 184-214 \mu \mathrm{m})$ and the spores of $A$. biseriale are more curved than those of A. gelatinosum.

\section{Arthrinium gelatinosum Y. Feng and Z.Y. Liu, sp. nov.} Figure 3

Index Fungorum number: IF558137

Facesoffungi number: FoF 09570

Etymology: The epithet refers to the ascospore surrounded by gelatinous sheath.
Holotype: HKAS 111962

Saprobic on dead bamboo culms, forming black, lenticular spots on the host surface, with stromata breaking through raised cracks with black center. Sexual morph: Stromata solitary to gregarious, immersed to erumpent, fusiform, with long axis broken at the top by one cracks. Ascomata 144-199 $\mu \mathrm{m}$ high $\mu \mathrm{m} \times 184-214 \mu \mathrm{m}$ wide, uniseriate or irregularly arranged beneath stromata, pseudothecial, black, globose to subglobose with a flattened base. Peridium composed of 5 or 6 layers of 
brown cells arranged in textura angularis, with a conspicuous perfusate ostiole. Hamathecium paraphyses hyphae-like. Asci 85$121 \mu \mathrm{m} \times 15-24 \mu \mathrm{m}(\bar{x}=100 \mu \mathrm{m} \times 17 \mu \mathrm{m}, n=20), 8$-spored, unitunicate, clavate, apically rounded, broadly cylindrical, with an indistinct pedicel. Ascospores (27-) 28-31 (-32) $\mu \mathrm{m} \times 6-$ $8 \mu \mathrm{m}(\bar{x}=30 \mu \mathrm{m} \times 7 \mu \mathrm{m}, n=30)$, apiosporic, clavate to fusiform with narrowly rounded ends, composed of a large guttate and small guttate, hyaline, smooth-walled, surrounded by a gelatinous sheath. Growing to a later stage, the guttate filled the entire spore, and the gelatinous sheath dissolves easily. Asexual morph: undetermined.

\section{Materials examined}

China, Guizhou Province, Chishui City, Zhuhai National Forest Park, on dead culms of bamboo, 10 July 2019, Yao Feng, CS1932 (HKAS 111962, holotype; GZAAS20-0108, isotype). Ibid., Chishui National Scenic Area, on dead branch of bamboo, 10 July 2019, Yao Feng, CS 19-29 (GZAAS 20-0107).

\section{Notes}

Two taxa representing Arthrinium gelatinosum cluster in a wellsupported lineage $(\mathrm{ML} / \mathrm{MP} / \mathrm{BI}=93 / 98 / 1$, Figure 1$)$, which is a sister to $A$. biseriale, and they are phylogenetically distinct species.

\section{Arthrinium septatum Y. Feng and Jian K. Liu, sp. nov. Figure 4}

Index Fungorum number: IF558138

Facesoffungi number: FoF 09571

Etymology: The epithet refers to the septate conidiophore.

Holotype: HKAS 111960

Saprobic on dead bamboo culms. Sexual morph: Stromata scattered to gregarious, immersed to erumpent, initially breaks through a black spot on the host, later visible as black, raised, lenticular or dome-shaped, and will grow into a linear shape at the later stage of growth. Ostiolate, with the long axis broken at the top revealing the ostioles of pseudothecia. Ascomata 88$195 \mu \mathrm{m}$ high $\times 160-185 \mu \mathrm{m}$ wide $(\bar{x}=140 \mu \mathrm{m} \times 173 \mu \mathrm{m}$, $n=10$ ), arranged in rows, brown to dark brown, subglobose with a flattened base. Peridium with several layers of cells arranged in textura angularis, with a conspicuous ostiole 50-90 $\mu \mathrm{m}$ in diameter, periphysate. Hamathecium paraphyses hyphae-like, septate, hyaline. Asci $75-104 \mu \mathrm{m} \times 17-26 \mu \mathrm{m}(\bar{x}=91 \mu \mathrm{m} \times 20$ $\mu \mathrm{m}, n=20), 8$-spored, clavate, cylindrical, apically rounded, with distinct pedicel. Ascospores (24-) 25-30 (-32) $\mu \mathrm{m} \times(6-) 8-$ $10(-11) \mu \mathrm{m}(\bar{x}=29 \mu \mathrm{m} \times 9 \mu \mathrm{m}, n=30)$, biseriate, broad fusiform to cylindrical, with a large upper cell and a small lower cell, hyaline, 1-septate, constricted at septum, slightly curved, smooth-walled, with many guttules, with a large guttule at the center of large upper cell, with a distinct gelatinous sheath. Asexual morph: On PDA, Hyphae 2-4 $\mu \mathrm{m}$ in diameter, hyaline, branched, septate. Conidiophores 12.0-63.0 $\times 2-5(\bar{x}=313$ $\mu \mathrm{m} \times 3 \mu \mathrm{m}, n=20$ ), straight or flexuous, smooth, thin-walled, septate, hyaline to light brown, cylindrical, sometimes reduced to conidiogenous cells. Conidiogenous cells 4.0-18.0 $\times 1.5-4.0$ $(\bar{x}=10.0 \mu \mathrm{m} \times 2.5 \mu \mathrm{m}, n=20)$, solitary on hyphae, integrated, branched, ampuliform, cylindrical, hyaline to brown. Conidia 8 $11(-13) \mu \mathrm{m}$ long $(n=30)$, brown, smooth, guttulate, globose to ellipsoid in surface view. and (8-) 9-13 (-14) $\mu \mathrm{m}$ long $(n=30)$, lenticular with a paler equatorial slit in side view. Sterile cells (13-) 14-21 (-27) $\mu \mathrm{m} \times 5-7(-9) \mu \mathrm{m}$ elongated, mixed among conidia.

\section{Culture characteristics}

Ascospores germinated on WA within $24 \mathrm{~h}$. Colonies on PDA reached $8 \mathrm{~cm}$ in 7 days at $25^{\circ} \mathrm{C}$, flat, aerial mycelium white. The hyphae in the center are cottony, dense, and there is a thin circle of hyphae at the edge. Reverse grayish white with a dirty white patch.

\section{Materials examined}

China, Guizhou Province, Chishui City, Zhuhai National Forest Park, on dead culms of bamboo, 10 July 2019, Yao Feng, CS198 (HKAS 111960, holotype; GZAAS 20-0109, isotype), ex-type living culture CGMCC 3.20134 = GZCC20-0108. Ibid., on dead branch of bamboo, 11 July 2019, Ya-Ya Chen, CS 025 (GZAAS 20-0111), living culture GZCC 20-0109.

\section{Notes}

Two isolates, representing Arthrinium septatum, grouped in a well-supported clade and appear to be distinct from other Arthrinium species phylogenetically (Figure 1). Arthrinium septatum resembles to A. biseriale in having biseriate, broad fusiform to cylindrical ascospores and cylindrical, clavate asci. However, Arthrinium septatum differs from A. biseriale by having smaller stromata (160-185 $\mu \mathrm{m}$ diam vs. $138-207 \mu \mathrm{m}$ diam) and asci $(75-104 \times 17-26 \mu \mathrm{m}$ vs. $84-116 \mu \mathrm{m} \times 18-25 \mu \mathrm{m})$.

\section{Arthrinium cyclobalanopsidis Y. Feng and Jian K. Liu, sp. nov. Figure 5}

Index Fungorum number: IF558139

Facesoffungi number: FoF 09572

Etymology: The epithet "cyclobalanopsidis" refers to the host plant, Cyclobalanopsidis glauca (Thunb.) Oerst.

Holotype: HKAS 111963

Saprobic on Cyclobalanopsidis glauca (Thunb.). Sexual morph: Undetermined. Asexual morph: On PDA, Hyphae 2.5-5.5 $\mu \mathrm{m}$ in diameter, hyaline, septate, branched with chain structure. Conidiophores reduced to the conidiogenous cells. Conidiogenous cells $\quad 6.0-19.0 \mu \mathrm{m} \quad \times \quad 2.5-7.0 \mu \mathrm{m}$ $(\bar{x}=11.0 \mu \mathrm{m} \times 4.5 \mu \mathrm{m}, n=20)$, aggregated in clusters on hypha, pale brown, ampuliform or cylindrical. Conidia 8-12 $\mu \mathrm{m}$ long $(n=30)$, brown, smooth, globose to ellipsoid in surface view, and 10-14 $\mu \mathrm{m}$ long $(n=30)$, lenticular, with a paler equatorial slit in side view. Sterile cells elongated, rolled up, sometimes mixed among conidia.

\section{Culture characteristics}

Conidia germinated on WA within $12 \mathrm{~h}$. Sporulated on PDA, Colonies flat, margin circular, fluffy, sparse, white, with dirty white patches in center, reverse white, with sparse aerial mycelium, reached $8 \mathrm{~cm}$ in 7 days at $25^{\circ} \mathrm{C}$.

\section{Material examined}

China, Guizhou Province, Qianxinan Buyi and Miao Autonomous Prefecture, Ceheng County, on Leaf of cyclobalanopsidis glauca (Thunb.) Oerst., 13 May 2018, Yao Feng, G81 (HKAS 111963, holotype; GZAAS 20-0096, isotype), 

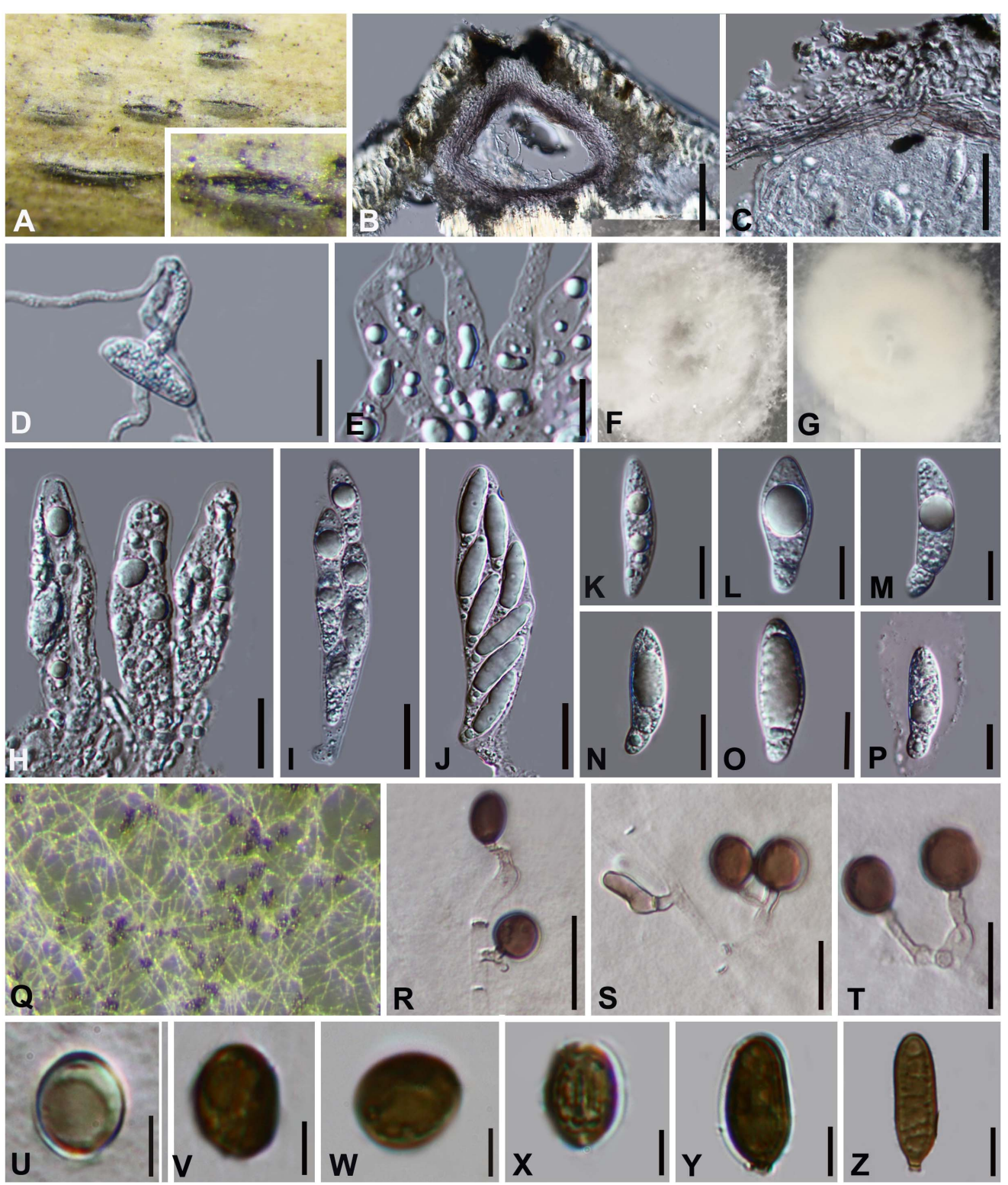

FIGURE 4 | Arthrinium septatum (HKAS 111960, holotype). (A) Appearance of stromata on bamboo host. (B) Vertical section of stroma. (C) Peridium. (D) Germinating ascospore. (E) Paraphyses. (F,G) Culture. (H-J) Asci. (K-P) Ascospore. (Q) Colony on PDA producing conidia masses. (R-T) Conidiophore and conidiogenous cells. (U-X) Conidia. (Y,Z) Sterile cell. Scale bars: (B) $=50 \mu \mathrm{m}$. (C,D) $=25 \mu \mathrm{m}$. (E) $=10 \mu \mathrm{m} . \mathbf{( H - J )}=20 \mu \mathrm{m} .(\mathbf{K}-\mathbf{P})=10 \mu \mathrm{m} .(\mathbf{R}-\mathbf{T})=10 \mu \mathrm{m}$. $(\mathbf{U}-\mathbf{Z})=5 \mu \mathrm{m}$.

ex-type living cultures, CGMCC 3.20136 = GZCC 20-0102. Ibid., 20 Oct. 2019, Yao Feng, G82 (GZAAS 20-0097), living culture GZCC 20-0103.

\section{Notes}

Two isolates, representing Arthrinium cyclobalanopsidis, cluster together with A. camelliae-sinensis which was introduced by Wang et al. (2018) from Camellia sinensis (Figure 1). Arthrinium cyclobalanopsidis can be distinguished from A. camelliaesinensis (567/572 in ITS; 390/414 in TEF; 715/748 in TUB2). Morphologically, Arthrinium cyclobalanopsidis resembles to
A. camelliae-sinensis in having similar conidia $(8-12 \mu \mathrm{m} \times 10-$ $14 \mu \mathrm{m}$ vs. $9.0-13.5 \mu \mathrm{m} \times 7.0-12.0 \mu \mathrm{m}$ ), but can be distinguished by its relatively longer conidiogenous cells $(6.0-19.0 \mu \mathrm{m}$ vs. $4.0-9.5 \mu \mathrm{m})$.

\section{Arthrinium garethjonesii D.Q. Dai and H.B. Jiang,} Mycosphere 7 (9): 1337 (2017). Figure 6

Saprobic on dead bamboo branch. Sexual morph: See Dai et al. (2016). Asexual morph: Sporodochia on host with hair-like setae, also grow in the gaps of the perithecia and scatter on the surface of the perithecia, black. Conidiophores reduced to conidiogenous 


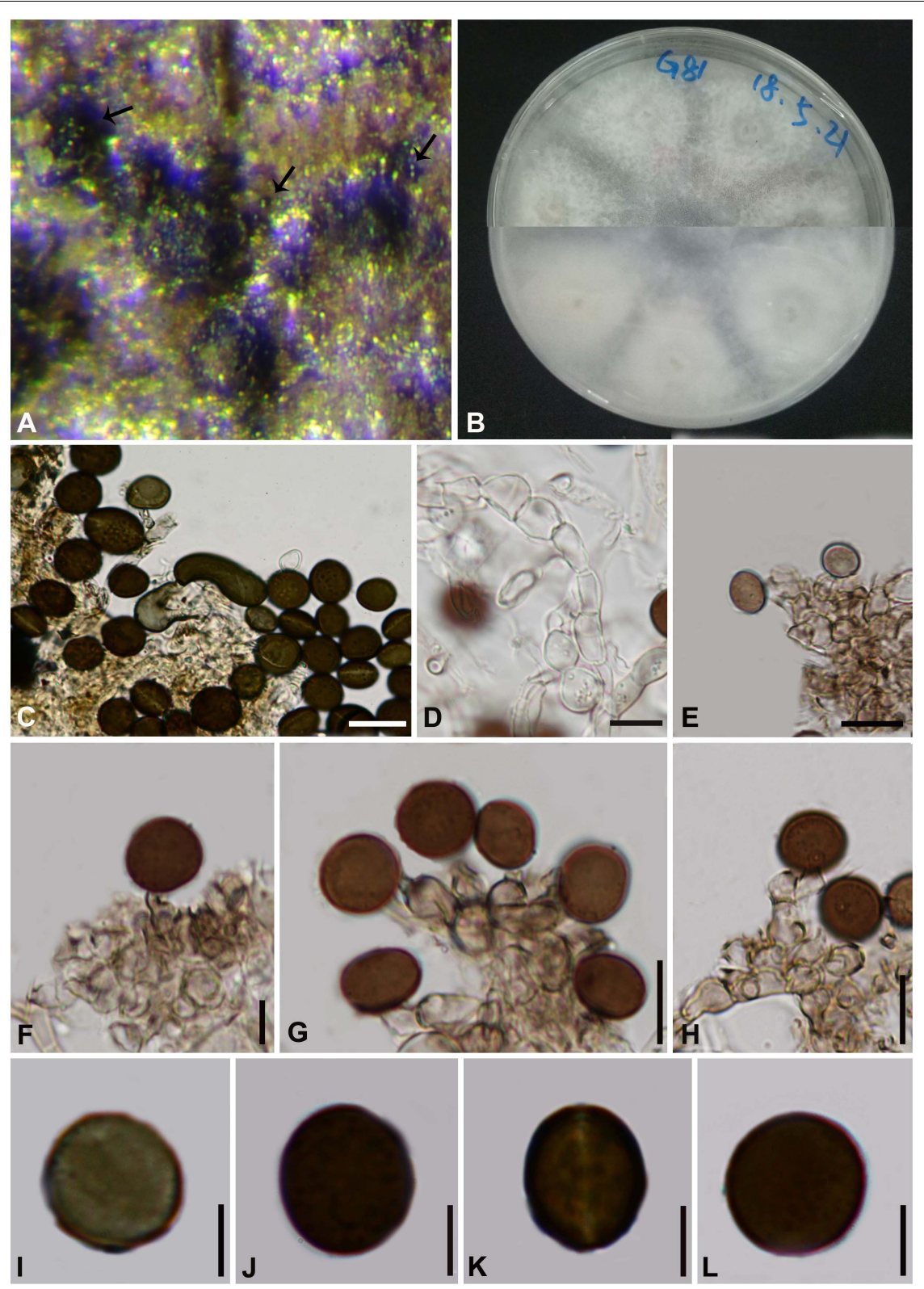

FIGURE 5 | Arthrinium cyclobalanopsidis (HKAS 111963, holotype) (A) Conidia masses on host. (B) Culture. (C) Sterile cell mixed among conidia. (D) Hyphae of chain structure. (E-H) Conidiogenous cells and conidia. (I-L) Conidia. Scale bars: $(\mathbf{C}-\mathbf{H})=10 \mu \mathrm{m}$. (I-L) $=5 \mu \mathrm{m}$.

cells. Conidiogenous cells (5-) 6-19 (-20) $\mu \mathrm{m} \times(2-) 3-5(-7)$ $\mu \mathrm{m}(\bar{x}=11 \mu \mathrm{m} \times 4 \mu \mathrm{m}, n=20)$, aggregated in black sporodochia, hyaline to pale brown, smooth, ampulliform. Conidia (14-) 16-19 (-20) $\mu \mathrm{m}$ diam, brown, smooth, granular, globose to subglobose in surface view, and (16-) 17-22 (-23) $\mu \mathrm{m}$ diam, with pale equatorial slit in side view.

\section{Culture characteristics}

Conidia germinated on WA within $12 \mathrm{~h}$, colonies fast growing on $\mathrm{PDA}$, reached $8 \mathrm{~cm}$ in 7 days at $25^{\circ} \mathrm{C}$, fluffy, circular, dense, raised at center, white, reverse reddish. Hyphae $2-4 \mu \mathrm{m}$ diam, hyaline to pale brown, branched, septate.

\section{Material examined}

China, Guizhou Province, Chishui City, Zhuhai National Forest Park, on dead branches of bamboo, 10 July 2019, Yao Feng, CS199 (GZAAS 20-0117); living culture GZCC 20-0115.

\section{Notes}

Arthrinium garethjonesii was originally described by Dai et al. (2016) based on the sexual morph from dead bamboo culms (HKAS 96289) collected from Yunnan Province, China. Our phylogenetic result (Figure 1) indicates that our collection is identical to Arthrinium garethjonesii and we report its asexual morph for the first time in this study. 

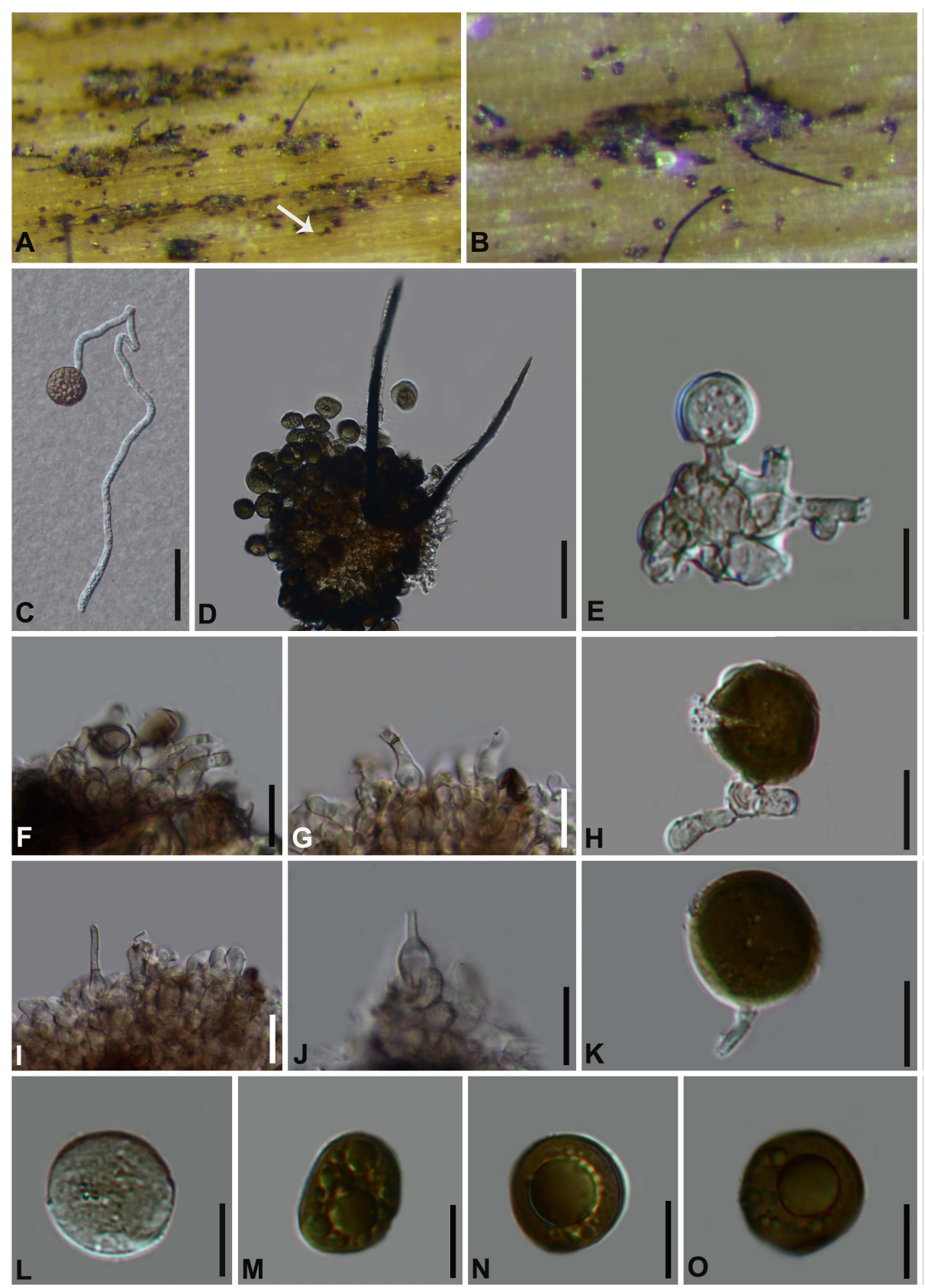

FIGURE 6 | Arthrinium garethjonesii (GZAAS 20-0117) (A,B) Appearance of sporodochia on bamboo host. (C) Germinating conidia. (D) Conidia with setae.

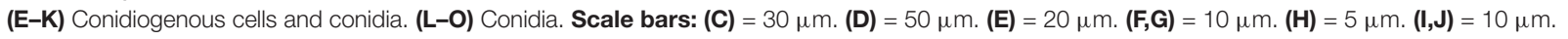
$(\mathbf{K}-\mathbf{O})=5 \mu \mathrm{m}$.

\section{Arthrinium guizhouense M. Wang and L. Cai, Mycokeys 34: 13 (2018). Figure 7}

Saprobic on dead bamboo culms, forming black, lenticular spots on the host surface, stromata breaking through raised cracks with black center. Sexual morph: Stromata solitary to gregarious, immersed to erumpent, fusiform, with long axis broken at the top by one cracks. Ascomata 188-220 $\mu \mathrm{m}$ high $\times 170-200 \mu \mathrm{m}$ wide, uniseriate or irregularly arranged beneath stromata, pseudothecial, black, globose to subglobose. Peridium composed of 5 or 6 layers of brown cells arranged in textura angularis, Hamathecium paraphyses 3-5 $\mu \mathrm{m}$, hyaline, hyphae-like, septate. Asci (80-) 94-106 $(-107) \mu \mathrm{m} \times(20-)$ 21-23 (-24) $\mu \mathrm{m}, 8$-spored, clavate, apically rounded, broadly cylindrical, with an indistinct pedicel. Ascospores (24-) 25-32 (-33) $\mu \mathrm{m} \times(6-) 7-9(-10) \mu \mathrm{m}$ $(\bar{x}=31 \mu \mathrm{m} \times 8 \mu \mathrm{m}, n=30)$, apiosporic, clavate to fusiform 

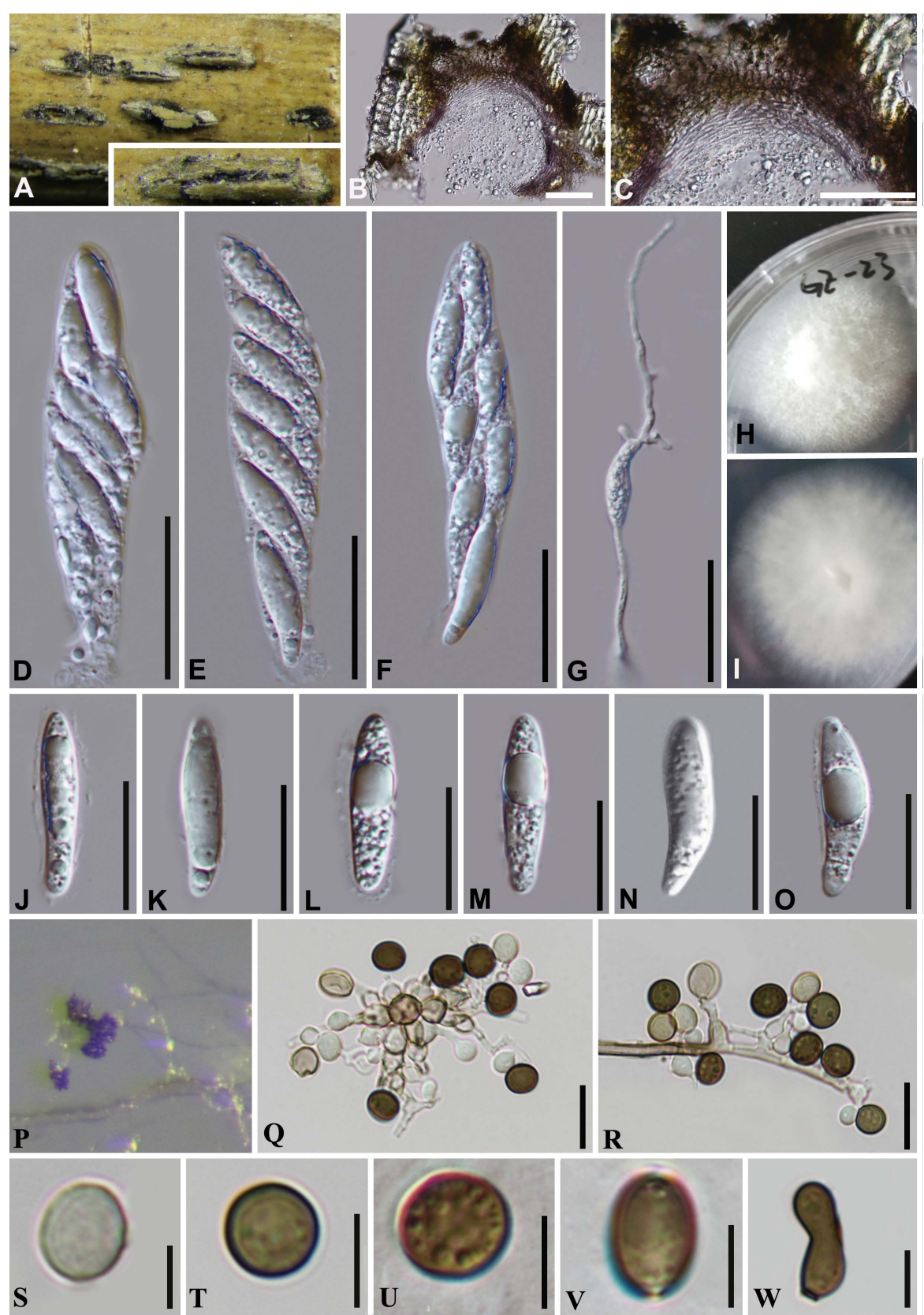

FIGURE 7 | Arthrinium guizhouense (GZAAS 20-0114). (A) Appearance of stromata on bamboo host. (B) Vertical section of stroma. (C) Peridium. (D-F) Asci. (G) Germinating ascospore. (H,I) Culture. (J-O) Ascospore. (P) Colony on WA producing conidia masses. $(\mathbf{Q}, \mathbf{R})$ Conidiogenous cells giving rise to conidia. (S-V) Conidia. (W) Sterile cell. Scale bars: (B,C) $=50 \mu \mathrm{m}$. (D-F) $=30 \mu \mathrm{m}$. (G) $=50 \mu \mathrm{m} .(\mathbf{J}-\mathbf{O})=20 \mu \mathrm{m} . \mathbf{( Q , R )}=10 \mu \mathrm{m}$. (S-W) $=5 \mu \mathrm{m}$.

with narrowly rounded ends, composed of a large upper cell and small lower cell, hyaline, smooth-walled, surrounded an inconspicuous gelatinous sheath. Asexual morph: Hyphae 2.5$7.5 \mu \mathrm{m}$ diam, hyaline, branched, septate. Conidiophores reduced to conidiogenous cells. Conidiogenous cells $4-12 \mu \mathrm{m} \times 2-$ $5 \mu \mathrm{m}(\bar{x}=8 \mu \mathrm{m} \times 3 \mu \mathrm{m}, n=20)$, erect, aggregated in clusters on hyphae, pale brown, smooth, subglobose, ampulliform or doliiform. Conidia 5-8 $\mu \mathrm{m}$ long $(n=30)$, dark brown to black, smooth, globose or subglobose, and
6-8 $\mu \mathrm{m}$ long $(n=30)$, lenticular, with a paler equatorial slit in side view. Sterile cells elongated, rolled up, sometimes mixed among conidia.

\section{Culture characteristics}

On PDA, colonies very fast, reached $8 \mathrm{~cm}$ in 8 days at $25^{\circ} \mathrm{C}$, velvety, circular, with regular edge, middle densely and raised white, dense at above the from margin, aerial mycelia, surface initially white, became grayish and reverse white. 


\section{Material examined}

China, Guangdong Province, Guangzhou City, on decaying bamboo culms, 03 Sep. 2019, Yao Feng, GZ 23 (GZAAS 20-0114); living culture GZCC 20-0114.

\section{Notes}

Arthrinium guizhouense was introduced from air in a karst cave (asexual morph was provided from the culture) in Guizhou province, China by Wang et al. (2018). In this study, one collection was found as saprobe on bamboo in Guangzhou, China and it is identified as A. guizhouense based on the phylogeny and morphology evidences. In addition, our new collection provides the sexual morph which only the asexual morph was illustrated by Wang et al. (2018) and Senanayake et al. (2020a).

\section{Arthrinium phyllostachium C.L. Yang, X.L. Xu and K.D. Hyde, Phytotaxa 406 (2): 102 (2019). Figure 8}

Saprobic on dead bamboo culms, Sexual morph: Stromata scattered to gregarious, immersed to erumpent, later becoming superficial, dark brown to black, fusiform, forming a slit-like opening at the apex, with stromata breaking through raised cracks with black center. Ascomata 135-185 $\mu \mathrm{m}$ high, 157-215 $\mu \mathrm{m}$ diam, multi-loculate, with a periphysate ostiole, arranged in rows, clustered, gregarious, ampulliform, dark brown to black. Peridium 20-25 $\mu \mathrm{m}$ wide, composed of several layers of dark brown to brown cells of textura angularis. Hamathecium 3-5 $\mu \mathrm{m}$ wide, comprising dense, hyaline, septate paraphyses, hyphaelike. Asci $66-98 \times 17-27(\bar{x}=85 \mu \mathrm{m} \times 21 \mu \mathrm{m}, n=20)$, 8 -spored, unitunicate, clavate, apedicellate, apically rounded. Ascospores $29-34 \mu \mathrm{m} \times 7-10 \mu \mathrm{m}(\bar{x}=32 \mu \mathrm{m} \times 9 \mu \mathrm{m}$, $n=30$ ), biseriate, elliptical, hyaline, 1 -septate, constricted at the septum, mostly curved at the lower cell, rarely straight, with a large upper cell and a small lower cell, smoothwalled, with a shallow gelatinous sheath. Asexual morph: On WA, Hyphae 1.5-4.0 $\mu \mathrm{m}$ in diameter, hyaline, septate, branched. Conidiophores reduced to the conidiogenous cells. Conidiogenous cells (8-) 9-28 (-31.5) $\mu \mathrm{m} \times(1.5-) 2-4$ $(-6) \mu \mathrm{m}(\bar{x}=20 \mu \mathrm{m} \times 3 \mu \mathrm{m}, n=20)$, aggregated in clusters on hypha or solitary, erect, ampuliform or cylindrical, arising holoblastically from vegetative hyphae, monoblastic, or polyblastic, sympodial, terminal, cylindrical to clavate, ampulliform, hyaline, smooth, thin-walled. Conidia 5-8 $\mu \mathrm{m}$ long $(n=30)$, brown, smooth, globose to ellipsoid in surface view, and 7-9 $\mu \mathrm{m}$ long $(n=30)$, lenticular, with a paler equatorial slit in side view. Sterile cells light brown, elongated, and occasionally irregularly angled.

\section{Culture characters}

Ascospores germinated on WA within $24 \mathrm{~h}$ and germ tubes produced from Upper, middle and lower end. Colonies fast growed on PDA at $25^{\circ} \mathrm{C}$, flat, spreading, the middle is white, smooth, the edge surface tapetum, gray-white, indistinct aerial hyphae, the reverse side is yellowish in the middle, and the edge is grayish white.

\section{Materials examined}

China, Guizhou Province, Chishui City, Zhuhai National Forest Park, on dead culms of bamboo, 10 July 2019, Yao Feng, CS 19-23
(GZAAS 20-0112), living culture GZCC 20-0111; Ibid., Chishui National Scenic Area, on dead culms of bamboo, 10 July 2019, Ya-Ya Chen, CS004 (GZAAS 20-0113), living culture GZCC 200112.

\section{Notes}

Arthrinium phyllostachium was introduced by Yang et al. (2019) based on the asexual morph and phylogeny analyses. It was collected from culms of Phyllostachys heteroclada (Poaceae) in China (Yang et al., 2019). The phylogenetic results showed that our new collections are identical to A. phyllostachium, Yang et al. (2019) only provided the asexual morph and the sexual morph is given in this study.

\section{Arthrinium pseudoparenchymaticum M. Wang and L. Cai, Mycokeys 34 (1): 17 (2018), Figure 9}

Saprobic on dead bamboo culms, forming black, lenticular spots on the host surface, with stromata breaking through raised cracks with black center. Sexual morph: Ascomata 187$242 \mu \mathrm{m}$ high $\times 242-373 \mu \mathrm{m}$ wide, uniseriate, or irregularly arranged beneath stromata, black, globose to subglobose with a flattened base. Peridium composed of 5-7 layers of brown cells arranged in textura angularis, with a conspicuous perfusate ostiole. Hamathecium paraphyses 4-8 $\mu \mathrm{m}$, hyphae-like, septa hyaline. Asci (95-) 107-110 (-133) $\mu \mathrm{m} \times 23-25(-27) \mu \mathrm{m}$, 8 -spored, broadly cylindrical, clavate or subglobose, apically rounded, with an indistinct pedicel. Ascospores (35-) 35$43(-44) \times(10-) 11-13 \mu \mathrm{m}(\bar{x}=41 \times 12, n=30)$, apiosporic, clavate to fusiform with narrowly rounded ends, composed of a large upper cell and small lower cell, hyaline, smooth-walled, surrounded by a gelatinous sheath. Asexual morph: On WA, Hyphae 1.5-4 $\mu \mathrm{m}$ diam, hyaline to pale brown, branched, septate. Conidiophore extends from the vegetative hypha, up to $60 \mu \mathrm{m}$ long. Conidiogenous cells 10.0$40.0 \mu \mathrm{m} \times 3.0-6.0 \mu \mathrm{m}$, scattered in clusters on hyphae, smooth, unbranched, hyaline to pale yellow, smooth, erect, subcylindrical. Conidia $17-27 \mu \mathrm{m} \times 17-21 \mu \mathrm{m}(\bar{x}=23 \mu \mathrm{m} \times 19$ $\mu \mathrm{m}, n=30$ ), pale to light brown, smooth, globose to subglobose, sometimes lobed or dentate, polygonal or irregular in surface view.

\section{Culture characteristics}

Ascospores germinating on WA within $24 \mathrm{~h}$ and germ tubes produced from upper. Colonies fast growing on $\mathrm{PDA}$ at $25^{\circ} \mathrm{C}$, under $12 \mathrm{~h}$ light $/ 12 \mathrm{~h}$ dark, cottony, circular, sparse, raised, with irregular edge, white in center.

\section{Material examined}

China, Guangdong Province, Guangzhou City, on decaying bamboo culms, 3 Sep. 2019, Yao Feng, GZ18 (GZAAS 20-0115), living culture GZCC20-0117.

\section{Notes}

Arthrinium pseudoparenchymaticum was introduced by Wang et al. (2018) based on the asexual morph characters and phylogeny analyses. It was originally collected from bamboo in China (Wang et al., 2018). In this study, a fresh specimen was collected and it 

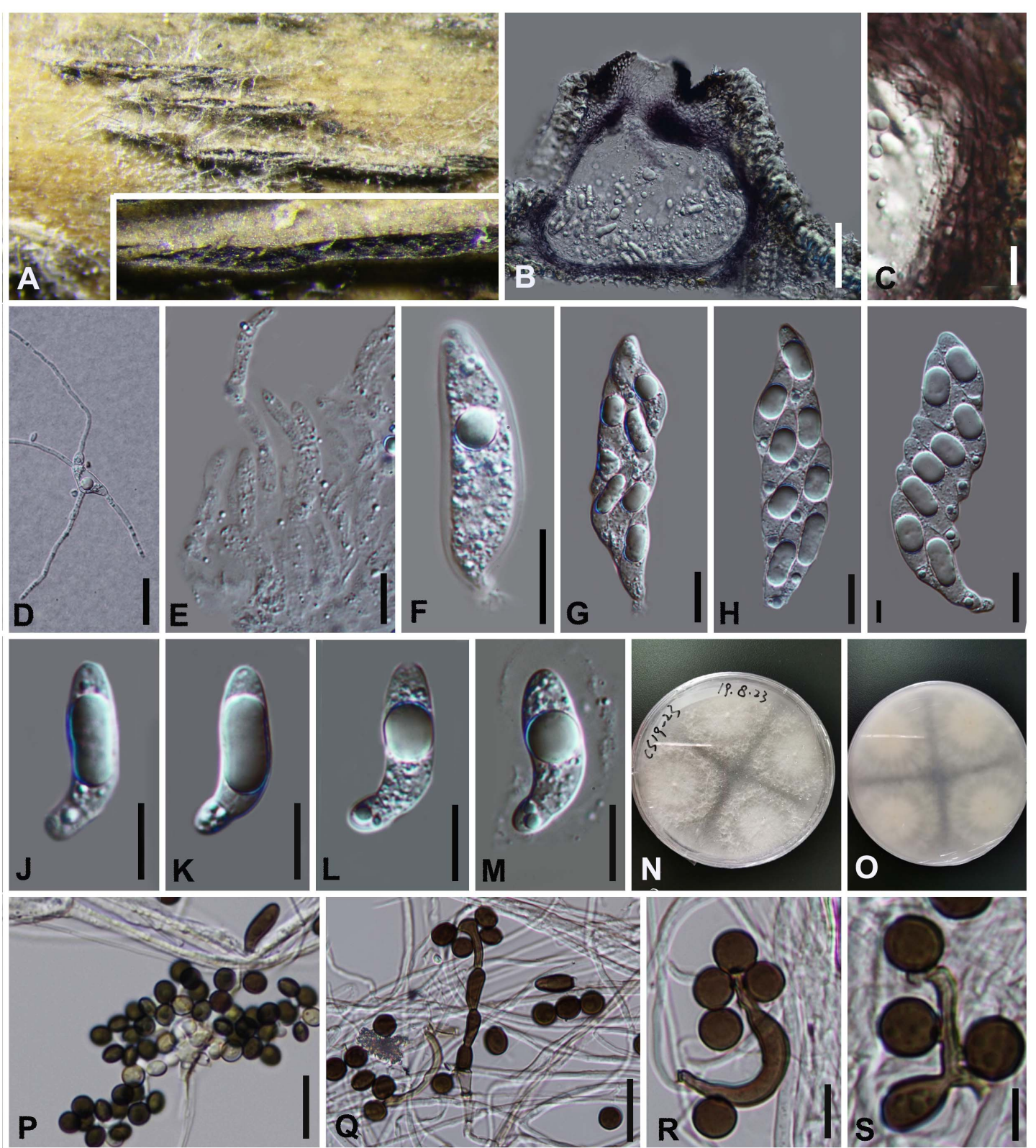

FIGURE 8 | Arthrinium phyllostachium (GZAAS 20-0112) (A) Appearance of stromata on bamboo host. (B) Vertical section of stroma. (C) Peridium.

(D) Germinating ascospore. (E) Paraphyses. (F-I) Asci. (J-M) Ascospore. (N,O) Culture. (P-S) Conidiogenous cells and conidia. Scale bars: (B) = 50 $\mu \mathrm{m}$. (C) = 10 $\mu \mathrm{m}$. (D) $=20 \mu \mathrm{m}$. (E) $=20 \mu \mathrm{m} .(\mathbf{F}-\mathbf{I})=30 \mu \mathrm{m} .(\mathbf{J}-\mathbf{M})=10 \mu \mathrm{m} .(\mathbf{P}, \mathbf{Q})=20 \mu \mathrm{m} . \mathbf{R}-\mathbf{S})=10 \mu \mathrm{m}$.

is identical to A. pseudoparenchymaticum (Figure 1), both sexual and asexual morphs were described and illustrated (Figure 9).

\section{Arthrinium arundinis (Corda) Dyko and B. Sutton, Mycotaxon 8: 119 (1979). Figure 10.}

Saprobic on dead bamboo culms. Asexual morph: On PDA, Hyphae 2-3 $\mu \mathrm{m}$ diam, consisting of smooth, hyaline, branched, septate. Conidiophores reduced to conidiogenous cells. Conidiogenous cells $3-8 \mu \mathrm{m} \times 2-$ $5 \mu \mathrm{m}$, aggregated in clusters on hyphae, pale brown, smooth, ampulliform. Conidia (4-) 5-6 (-7) $\mu \mathrm{m}$, brown, smooth, globose in surface view, and (4-) 5-7 (-8) $\mu \mathrm{m}$ diam, lenticular with pale equatorial slit in side view. Sterile cells at times intermingled among conidia. Sexual morph: Undetermined.

\section{Culture characteristics}

The colony is flat, cotton-like, thick and dense, with sparse aerial mycelia. The surface of PDA is white and the reverse side is grayish white. 

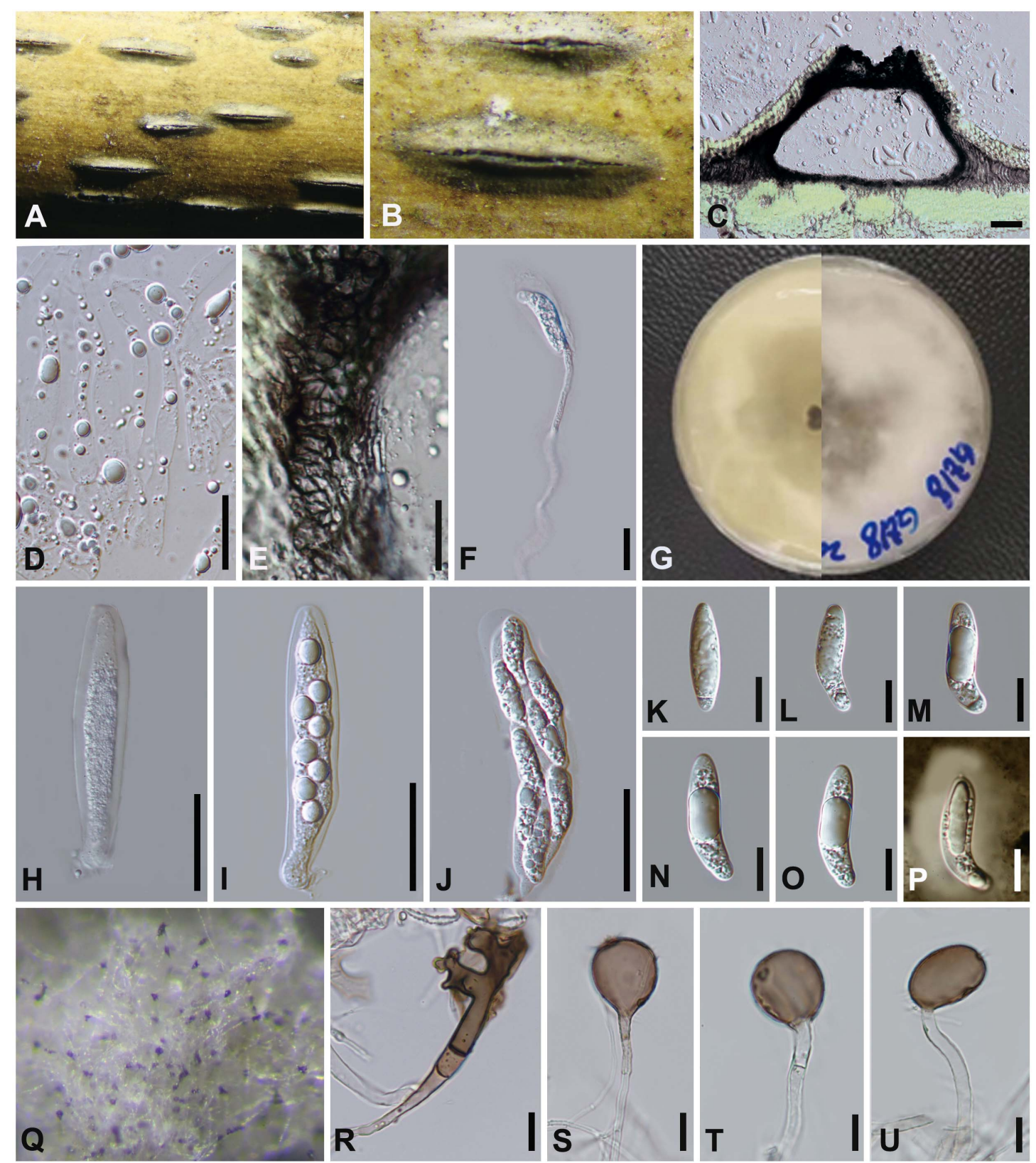

FIGURE 9 | Arthrinium pseudoparenchymaticum (GZAAS 20-0115) (A,B) Appearance of stromata on bamboo host. (C) Vertical section of stroma. (D) Paraphyses. (E) Peridium. (F) Germinating ascospore. (G) Culture. (H-J) Asci. (K-O) Ascospore. (P) Ascospore in Indian ink and present clear gelatinous

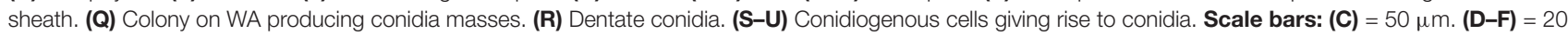
$\mu \mathrm{m}$. (H-J) $=30 \mu \mathrm{m}$. (K-P) $=15 \mu \mathrm{m}$. (R-U) $=15 \mu \mathrm{m}$.

\section{Materials examined}

China, Guizhou Province, Chishui City, Zhuhai National Forest Park, on dead culms of bamboo, 10 July 2019, Yao Feng, CS 19-7 (GZAAS 20-0116), living culture GZCC 20-0116.

\section{Notes}

Our collection clusters together with the isolates of Arthrinium arundinis (Figure 1) and its morphology lines up with the type species. Therefore we identify it as Arthrinium arundinis.
Arthrinium hydei Crous, IMA Fungus 4 (1): 142 (2013). Figure 11

Saprobic on bamboo leaves. Asexual morph: Colonies on the host punctiform, pulvinate, blackish brown. Conidiophores pale brown, smooth, transversely septate, subcylindrical. Conidiogenous cells 5-15 $\times 3-6 \mu \mathrm{m}$, brown, smooth, subcylindrical to doliiform to lageniform. Conidia (13-) 14-19 (-20) $\mu \mathrm{m}$ diam in surface view, brown, roughened, globose, and 15-20 $\mu \mathrm{m}$ diam, 

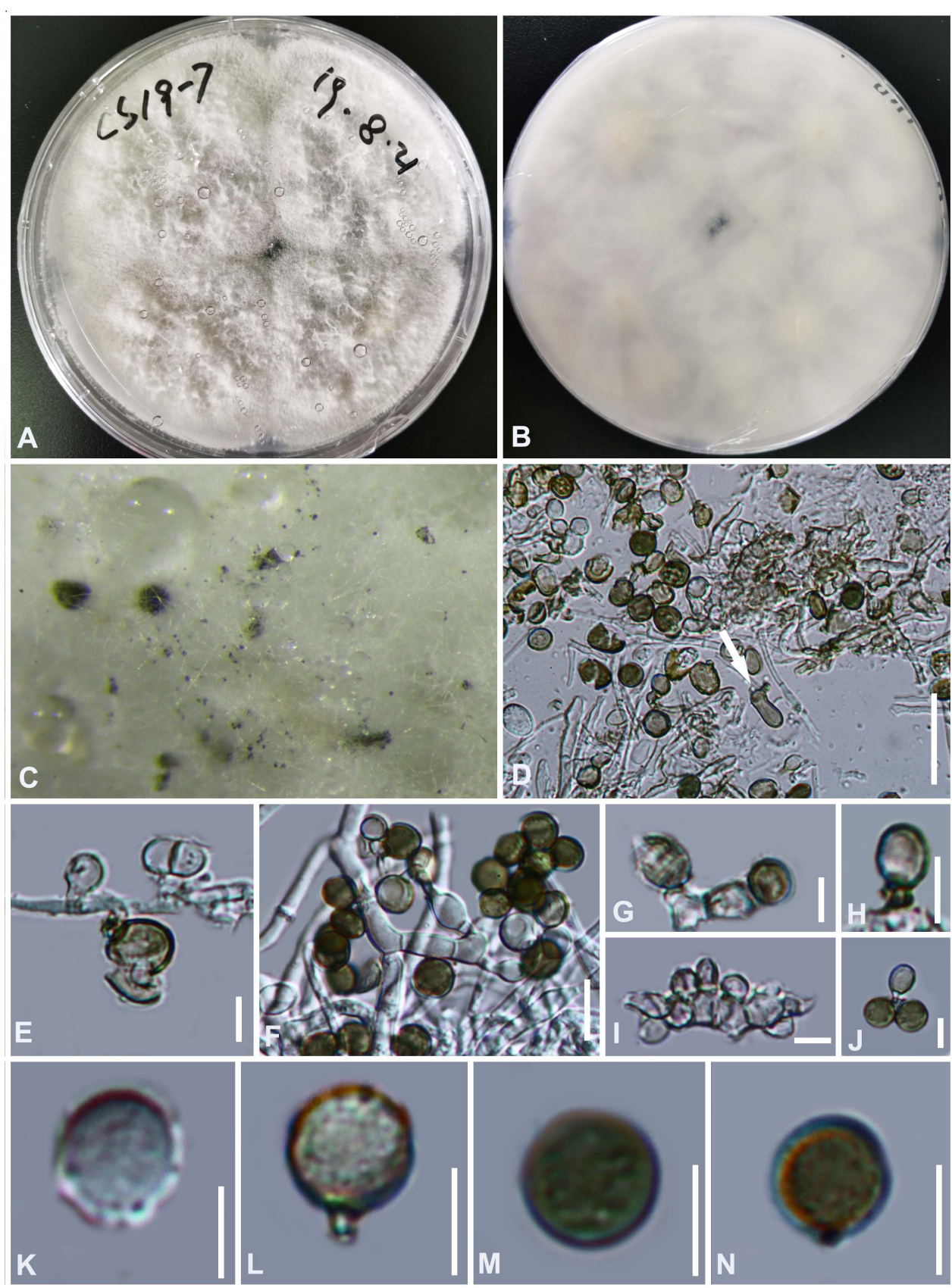

FIGURE 10| Arthrinium arundinis (GZAAS 20-0116) (A,B) culture. (C) Colonies on culture. (D) Sterile cell mixed among conidia. (E-J) Conidiogenous cells and conidia. (K-N) Conidia. Scale bars: (D) $=50 \mu \mathrm{m}$. (E) $=5 \mu \mathrm{m}$. (F) $=10 \mu \mathrm{m}$. (G-N) $=5 \mu \mathrm{m}$.

lenticular with pale equatorial slit in side view. Sexual morph: Undetermined.

\section{Culture characteristics}

Colonies flat, spreading, with sparse aerial mycelium. On PDA surface and reverse pale luteous. Mycelium consisting of smooth, hyaline to pale brown, branched, septate, 2.0-4.5 $\mu \mathrm{m}$ diam hyphae.

\section{Materials examined}

China, Guizhou Province, Guiyang City, Baihua Lake, on bamboo leaves, 20 April 2018, Yao Feng, 67 (GZAAS 20-0098), living culture GZCC20-0113.

\section{Notes}

This collection is identified as Arthrinium hydei based on both morphological characters and molecular data. Crous and Groenewald (2013) originally described A. hydei 

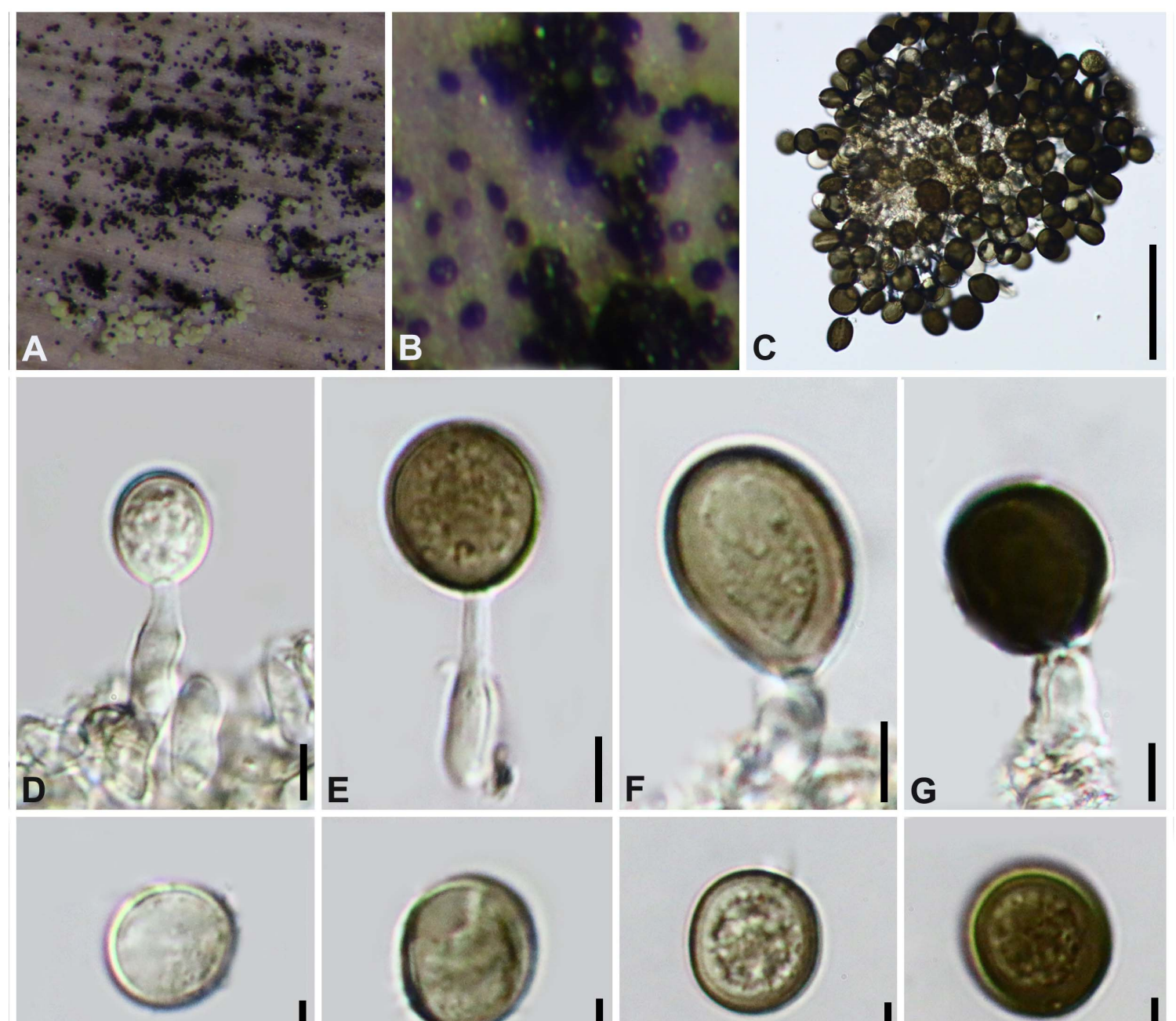

H
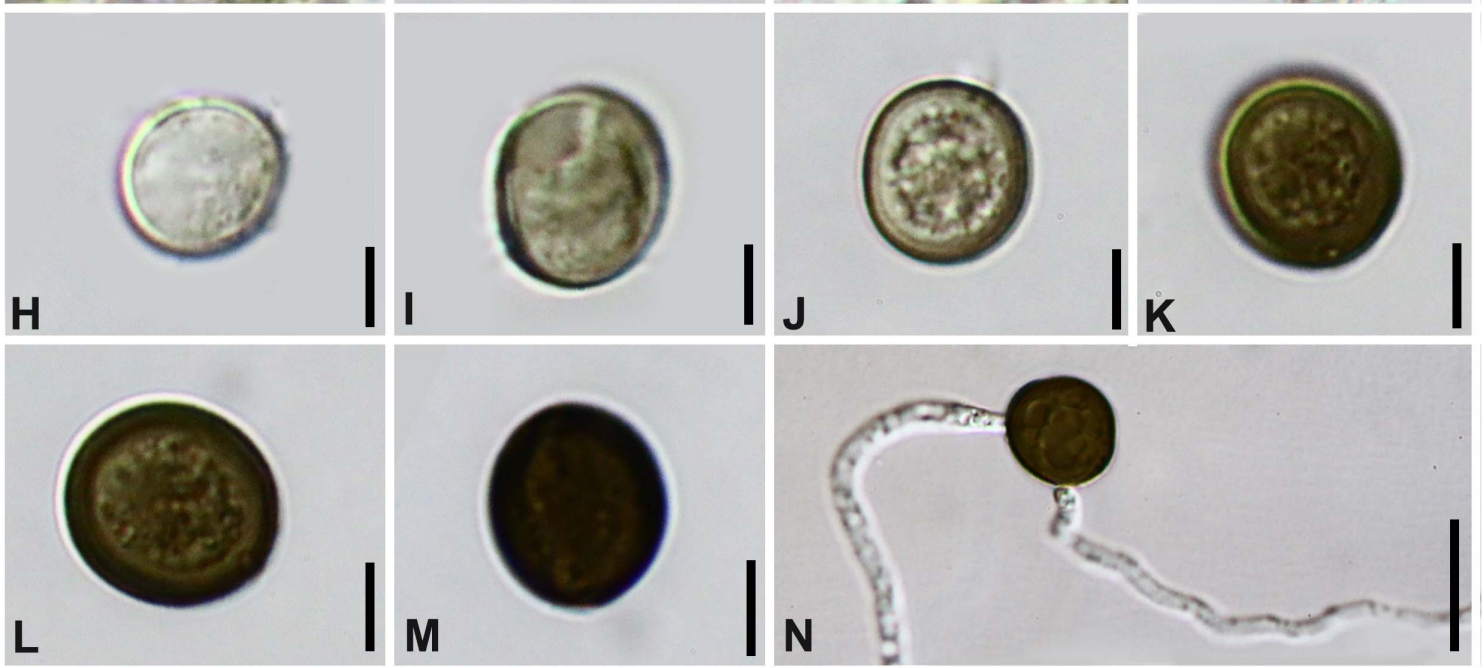

FIGURE 11 | Arthrinium hydei (GZAAS 20-0098) (A,B) Colonies on substrate. (C-F) Conidiogenous cells and conidia. (G-M) Conidia. (N) Germinating conidia. Scale bars: (C) $=50 \mu \mathrm{m}$. (D-M) $=5 \mu \mathrm{m}$. (N) $=25 \mu \mathrm{m}$.

based on the asexual morph from a culture (CBS 114990) which was isolated from bamboo culms in Hong Kong, China; we found this species in Guizhou from the substrate in nature with its asexual morph.

Arthrinium neosubglobosa D.Q. Dai and H.B. Jiang, Mycosphere 7 (9): 1337 (2017) Figure 12.

Saprobic on dead bamboo culms. Sexual morph: Stromata scattered to gregarious, superficial to raised, with a slit-like opening, dark brown to black, naviculate, with black papillate ostiole, multi-loculate. Ascomata 205-328 $\mu \mathrm{m}$ high, 168-345 $\mu \mathrm{m}$, perithecial, arranged in a row, immersed in stromata, later becoming erumpent through host surface to superficial, obpyriform to ampulliform, dark brown, membranous. Ostiole raised from center of Ascomata, internally lined with periphyses. Peridium 4 layers, outer layer composed of dark brown, cells of textura prismatica, inner layer thin, with hyaline cells of textura angularis. Hamathecium 4.0-5.5 $\mu \mathrm{m}$ wide, comprising dense 

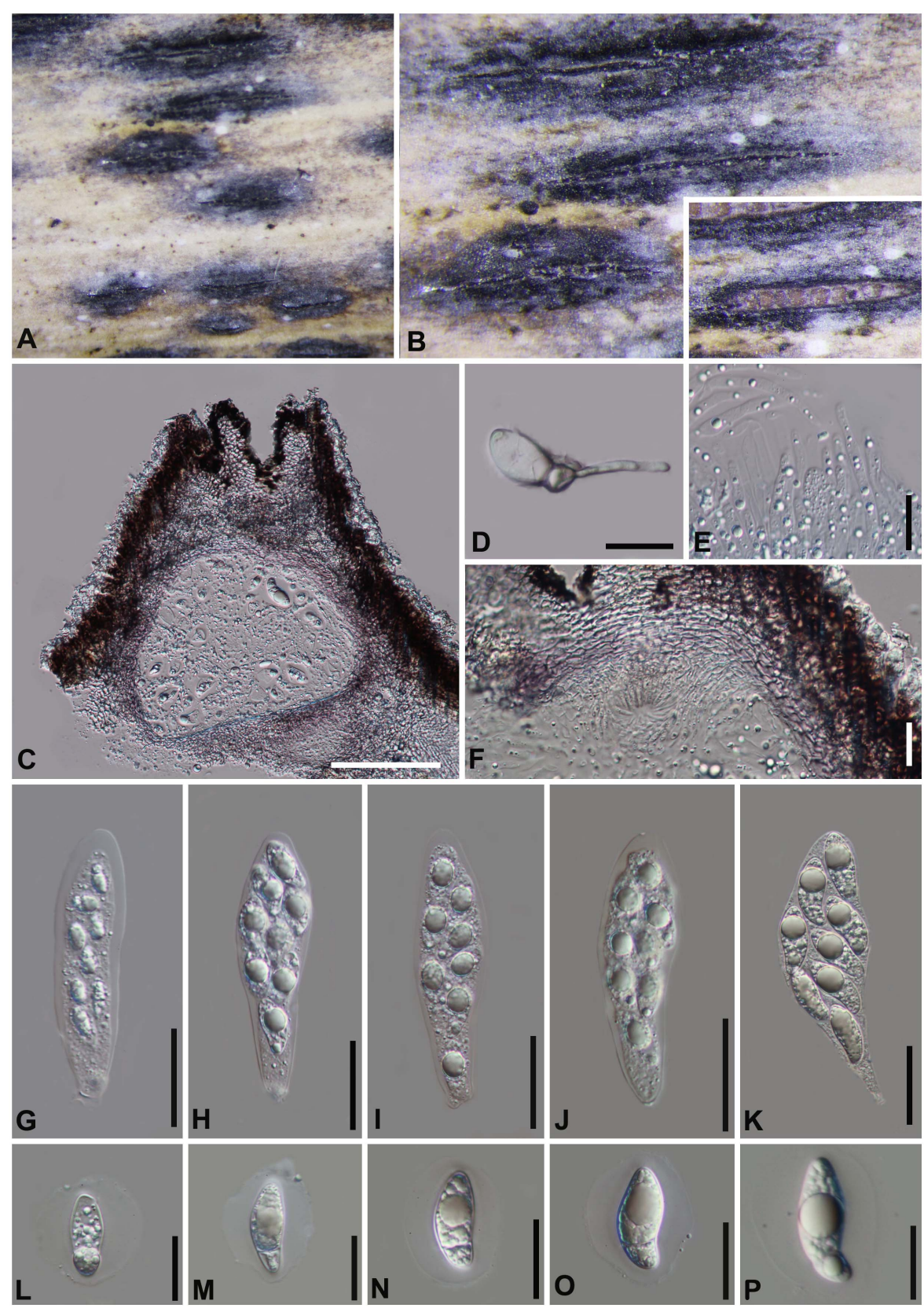

FIGURE 12 | Arthrinium neosubglobosa (GZAAS 20-0099). (A,B) Appearance of stromata on bamboo host. (C) Vertical section of stroma. (D) Germinating ascospore. (E) Paraphyses. (F) Peridium. (G-K) Asci. (L-P) Ascospore. Scale bars: (C) $=100 \mu \mathrm{m}$. (D-F) $=20 \mu \mathrm{m}$. (G-K) $=30 \mu \mathrm{m}$. (L-P) $=20 \mu \mathrm{m}$.

paraphyses, indistinctly aseptate, unbranched, not anastomosing, filamentous, clustered embedded in gelatinous matrix. Asci $80-119 \mu \mathrm{m} \times 20-37 \mu \mathrm{m}(\bar{x}=97 \mu \mathrm{m} \times 28 \mu \mathrm{m}, n=20)$, 8 -spored, unitunicate, clavate, with a short pedicel, apically rounded. Ascospores $25-36 \mu \mathrm{m} \times 11-15 \mu \mathrm{m}(\bar{x}=29 \mu \mathrm{m} \times 13$ $\mu \mathrm{m}, n=30$ ), 2-seriate, elliptical, hyaline, 1-septate, constricted at the septum, mostly curved at the lower cell, rarely straight, with a large upper cell and a small lower cell, smoothwalled, 1-guttulate, with a shallow 8-12 $\mu \mathrm{m}$ thick gelatinous sheath. Asexual morph: Undetermined.

\section{Materials examined}

China, Guizhou Province, Zunyi City, Daozhen County, on dead culms of bamboo, 15 August 2018, Yao Feng, DZ22 (GZAAS 200099).

\section{Notes}

Arthrinium neosubglobosa was introduced by Dai et al. (2016) based on the sexual morph characters and phylogeny analyses. The pure culture was attempted by single spore isolation and the DNA was extracted directly from the fruiting body, the 
new collection is identified as A. neosubglobosa based on the phylogeny (Figure 1) and morphology evidences.

\section{DISCUSSION}

Arthrinium species have been reported from many hosts, includes hive-stored pollen lichens, marine algae, soil debris, gut of insects and nodules of human skin (Sharma et al., 2014; Crous et al., 2015, Senanayake et al., 2015; Wijayawardene et al., 2017, Zhao et al., 2018), it can be concluded that Arthrinium is ecologically diverse. Bamboo, as one of the most reported host, is a gramineous plant integrating economy and ornamental value (Gratani et al., 2008; Kelchner and Bamboo Phylogeny Group, 2013; Dai et al., 2016, 2017; Jiang et al., 2018, 2019, 2020; Wang et al., 2018; Yang et al., 2019), there is more than 115 genera with approximately 1,450 species. According to incomplete statistics, more than 1,100 species of fungi on bamboo were reported (Hyde et al., 2002a,b; Dai et al., 2016, 2017; Senanayake et al., 2020a; Tang et al., 2020; Wijesinghe et al., 2020). It is of great significance to excavate and identify the fungi on bamboo.

Several studies have shown (Crous and Groenewald, 2013; Dai et al., 2016, Dai et al., 2017; Wang et al., 2018; Yang et al., 2019) that it is difficult to identify the Arthrinium species solely rely on morphology and the multi-gene phylogenetic analyses are needed in the identification and classification of Arthrinium. The morphology of conidia is variable which can be depending on the period of incubation on different habitats, for example, A. biseriale, A. gelatinosum and A. septatum, are very similar in morphology, but molecular data distinguish them into different species; Our collection A. pseudoparenchymaticum differs from the type specimen (LC 8173) in the morphology of conidiophores, the size of conidiogenous cells is also different, while the molecular data supported them as the same species. These results are in agreement with the previous observations and publications (Crous and Groenewald, 2013; Dai et al., 2016, Dai et al., 2017; Wang et al., 2018, Yang et al., 2019). In addition, as a high diverse group, it is also difficult to distinguish species within Arthrinium by only using ITS and LSU gene regions, and the protein genes (TEF and TUB2) are not available for many species in the genus which bring potential problem once the new or existing taxa are introduced and identified, respectively. For example the absent of the protein genes (TEF and TUB2) of Arthrinium garethonesii would bring the troubles

\section{REFERENCES}

Agut, M., and Calvo, M. A. (2004). In vitro conidial germination in Arthrinium aureum and Arthrinium phaeospermum. Mycopathologia 157, 363-367. doi: 10.1023/B:MYCO.0000030432.08860.f3

Carbone, I., and Kohn, L. M. (1999). A method for designing primer sets for speciation studies in filamentous ascomycetes. Mycologia 91, 553-556. doi: 10.1080/00275514.1999.12061051

Chen, Y. Y., Dissanayake, A., Liu, Z. Y., and Liu, J. K. (2020). Additions to Karst Fungi 4: Botryosphaeria spp. associated with woody hosts in Guizhou province, China including B. guttulata sp. nov. Phytotaxa 454, 186-202. doi: 10.11646/ phytotaxa.454.3.2 in identification of Arthrinium setostromum as it is hard to confirm whether they are same species or not as they are identical in ITS and LSU gene regions, as well as the close phylogenetic relationship (Figure 1). It would be necessary to provide protein genes when new taxa are introduced in these well-study and diverse groups.

\section{DATA AVAILABILITY STATEMENT}

The data presented in the study can be found in the Genbank. The accession numbers of the sequences deposited in GenBank are ITS: MW481705-MW481721; LSU: MW478885-MW478901; TEF:MW522938-MW522954; and TUB: MW522955-MW522969.

\section{AUTHOR CONTRIBUTIONS}

YF and J-KL: conceptualization. YF and Y-YC: methodology. YF, C-GL, and J-KL: formal analysis. YF, Y-YC, M-MX, and J-KL: resources. YF: writing-original draft preparation. C-GL, $\mathrm{Z}-\mathrm{YL}$, and J-KL writing-review and editing. Z-YL and J-KL: supervision. All authors approved to publish the version of final manuscript.

\section{FUNDING}

This study was supported by the Joint Fund of the National Natural Science Foundation of China and the Karst Science Research Center of Guizhou province (Grant No. U1812401); the Research of Featured Microbial Resources and Diversity Investigation in Southwest Karst area (Project No. 2014FY120100); and the Guizhou Graduate Research Funding: Taxonomic and Phylogenetic studies of microfungi from Bamboo in Guizhou (Qian Jiao He YJSCXJH [2019] 022).

\section{ACKNOWLEDGMENTS}

We thank Ning-Guo Liu, Sheng-Nan Zhang, Jing Yang, Qiu-Jiu Shang, and Milan C. Samarakoon for their suggestions on phylogeny in this study.

Chen, Y. Y., Maharachchikumbura, S. S. N., Liu, J. K., Hyde, K. D., Nanayakkara, R. R., Zhu, G. S., et al. (2017). Fungi from asian karst formations I. Pestalotiopsis photinicola sp.nov., causing leaf spots of Photinia serrulata. Mycosphere 8, 103-110. doi: 10.5943/mycosphere/8/1/9

Crous, P. W., and Groenewald, J. Z. (2013). A phylogenetic re-evaluation of Arthrinium. IMA Fungus 4, 133-154. doi: 10.5598/imafungus.2013.04.01.13

Crous, P. W., Wingfield, M. J., Le Roux, J. J., Richardson, D. M., Strasberg, D., Shivas, R. G., et al. (2015). Fungal planet description sheets: 371-399. Persoonia 35, 264-327. doi: 10.3767/003158515X690269

Dai, D. Q., Jiang, H. B., Tang, L. Z., and Bhat, D. J. (2016). Two new species of Arthrinium (Apiosporaceae, Xylariales) associated with bamboo from Yunnan, China. Mycosphere 7, 1332-1345. doi: 10.5943/mycosphere/7/9/7 
Dai, D. Q., Phookamsak, R., Wijayawardene, N. N., Li, W. J., Bhat, D. J., Xu, J. C., et al. (2017). Bambusicolous fungi. Fung. Divers. 82, 1-105.

Dissanayake, A. J., Bhunjun, C. S., Maharachchikumbura, S. S. N., and Liu, J. K. (2020a). Applied aspects of methods to infer phylogenetic relationships amongst fungi. Mycosphere 11, 2652-2676. doi: 10.5943/mycosphere/ $11 / 1 / 18$

Dissanayake, A. J., Chen, Y. Y., and Liu, J. K. (2020b). Unravelling diaporthe species associated with woody hosts from karst formations (Guizhou) in China. J. Fungi 6:251. doi: 10.3390/jof6040251

Ellis, M. B. (1971). Dematiaceous Hyphomycetes. Kew: Commonwealth Mycological Institute, 608.

Feng, Y., Zhang, S. N., and Liu, Z. Y. (2019). Tremateia murispora sp. nov. (Didymosphaeriaceae, Pleosporales) from Guizhou, China. Phytotaxa 416, 7987. doi: $10.11646 /$ phytotaxa.416.1.10

Glass, N. L., and Donaldson, G. C. (1995). Development ofprimer sets designed for use with the PCR to amplify conserved genes from filamentous ascomycetes. Appl. Environ. Microbiol. 61, 1323-1330. doi: 10.1128/aem.61.4.1323-1330. 1995

Gratani, L., Crescente, M. F., Varone, L., Fabrini, G., and Digiulio, E. (2008). Growth pattern and photosynthetic activity of different bamboo species growing in the Botanical Garden of Rome. Flora Morphol. Distrib. Funct. Ecol. Plants 203, 77-84. doi: 10.1016/j.flora.2007.11.002

Hall, T. A. (1999). "BioEdit: a user-friendly biological sequence alignment editor and analysis program for Windows 95/98/NT," in Nucleic Acids Symposium Series. 95-98.

Hillis, D. M., and Bull, J. J. (1993). An empirical test of bootstrapping as a method for assessing confidence in phylogenetic analysis. Syst. Biol. 42, 182-192. doi: $10.1093 /$ sysbio/42.2.182

Huelsenbeck, J. P., and Ronquist, F. (2001). MRBAYES: bayesian inference of phylogenetic trees. Bioinformatics 17, 754-755. doi: 10.1093/bioinformatics/17. 8.754

Hyde, K. D., Fröhlich, J., and Taylor, J. E. (1998). Fungi from palms. XXXVI. Reflections on unitunicate ascomycetes with apiospores. Sydowia 50, 21-80.

Hyde, K. D., Norphanphoun, C., Maharachchikumbura, S. S. N., Bhat, D. J., Jones, E. B. G., Bundhun, D., et al. (2020). Refined families of Sordariomycetes. Mycosphere 11, 305-1059. doi: 10.5943/mycosphere/11/1/7

Hyde, K. D., Zhou, D., and Dalisayl, T. (2002a). Bambusicolous fungi: a review. Fung. Divers. 9, 1-14.

Hyde, K. D., Zhou, D., McKenzie, E., Ho, W., and Dalisay, T. (2002b). Vertical distribution of saprobic fungi on bamboo culms. Fungal Divers. 11, 109-118.

Jayasiri, C. S., Hyde, K. D., Ariyawansa, H. A., Bhat, J., Buyck, B., Cai, L., et al. (2015). The faces of fungi database: fungal names linked with morphology, phylogeny and human impacts. Fungal Divers. 74, 3-18. doi: 10.1007/s13225015-0351-8

Jiang, H. B., Hyde, K. D., Doilom, M., Karunarathna, S. C., Xu, J. C., and Phookamsak, R. (2019). Arthrinium setostromum (Apiosporaceae, Xylariales), a novel species associated with dead bamboo from Yunnan, China. Asia. J. Mycol. 2, 254-268. doi: 10.5943/ajom/2/1/16

Jiang, N., Li, J., and Tian, C. M. (2018). Arthrinium species associated with bamboo and reed plants in China. Fungal Syst. Evol. 2, 1-9. doi: 10.3114/fuse.2018. 02.01

Jiang, N., Liang, Y. M., and Tian, C. M. (2020). A novel bambusicolous fungus from China, Arthrinium chinense (Xylariales). Sydowia 72, 77-83. doi: 10.12905/ 0380

Katoh, K., and Standley, D. M. (2013). MAFFT multiple sequence alignment software version 7: improvements in performance and usability. Mol. Biol. Evol. 30, 772-780. doi: 10.1093/molbev/mst010

Kelchner, S. A., and Bamboo Phylogeny Group (2013). Higher level phylogenetic relationships within the bamboos (Poaceae: Bambusoideae) based on five plastid markers. Mol. Phylogenet. Evol. 67, 404-413. doi: 10.1016/j.ympev.2013. 02.005

Li, B. J., Liu, P. Q., Jiang, Y., Weng, Q. Y., and Chen, Q. H. (2016). First report of culm rot caused by Arthrinium phaeospermum on Phyllostachys viridis in China. Plant Dis. 100, 1013-1013. doi: 10.1094/PDIS-08-15-0901-PDN

Liu, J. K., Chomnunti, P., Cai, L., Phookamsak, R., Chukeatirote, E., Jones, E. B. G., et al. (2010). Phylogeny and morphology of Neodeightonia palmicola sp. nov. from palms. Sydowia 62, 261-276.
Liu, N. G., Bhat, D. J., Hyde, K. D., and Liu, J. K. (2019). Conioscypha tenebrosa sp. nov. (Conioscyphaceae) from China and notes on Conioscypha species. Phytotaxa 413, 159-171. doi: 10.11646/phytotaxa.413.2.5

Luo, Z., Hyde, K. D., Liu, J. K., Maharachchikumbura, S. S. N., Jeewon, R., Bao, D. F., et al. (2019). Freshwater Sordariomycetes. Fungal Divers. 99, 451-660. doi: 10.1007/s13225-019-00438-1

Mapook, A., Hyde, K. D., McKenzie, E. H. C., Gareth, J. E. B., Bhat, D. J., Jeewon, R., et al. (2020). Taxonomic and phylogenetic contributions to fungi associated with the invasive weed Chromolaena odorata (Siam weed). Fungal Divers. 101, 1-175. doi: 10.1007/s13225-020-00444-8

Martínez-Cano, C., Grey, W. E., and Sands, D. C. (1992). First report of Arthrinium arundinis causing kernel blight on barley. Plant Dis. 76, 1077. doi: 10.1094/PD76-1077B

Mavragani, D. C., Abdellatif, L., McConkey, B., Hamel, C., and Vujanovic, V. (2007). First report of damping-off of durum wheat caused by Arthrinium sacchari in the semi-arid Saskatchewan fields. Plant Dis. 91:469. doi: 10.1094/ pdis-91-4-0469a

Nylander, J. A. A. (2004). MrModeltest v2. Program Distributed by the Author. Uppsala: Evolutionary Biology Centre, Uppsala University.

O’Donnell, K., and Cigelnik, E. (1997). Two divergent intragenomic rDNA ITS2 types within a monophyletic lineage of the fungus Fusarium are nonorthologous. Mol. Phylogenet. Evol. 7, 103-116. doi: 10.1006/mpev.1996. 0376

O’Donnell, K., Kistler, H. C., Cigelnik, E., and Ploetz, R. C. (1998). Multiple evolutionary origins of the fungus causing Panama disease of banana: concordant evidence from nuclear and mitochondrial gene genealogies. Proc. Natl. Acad. Sci. U.S.A. 95, 2044-2049. doi: 10.1073/pnas.95.5.2044

Pintos, A., Alvarado, P., Planas, J., and Jarling, R. (2019). Six new species of Arthrinium from Europe and notes about A. caricicola and other species found in Carex spp. Hosts. Mycokeys 49, 15-48. doi: 10.3897/mycokeys.49.32115

Rai, M. K. (1989). Mycosis in man due to Arthrinium phaeospermum var. indicum. First case report. Mycoses 32, 472-475. doi: 10.1111/j.1439-0507.1989.tb0 2285.x

Rambaut, A. (2012). ). FigTree, Version 1.4. 2. Edinburgh: University of Edinburgh.

Rannala, B., and Yang, Z. (1996). Probability distribution of molecular evolutionary trees: a new method of phylogenetic inference. J. Mol. Evol. 43, 304-311. doi: 10.1007/BF02338839

Seifert, K., Morgan-Jones, G., Gams, W., and Kendrick, B. (2011). The Genera of Hyphomycetes.[CBS Biodiversity Series 9]. Utrecht: CBS-KNAW Fungal Biodiversity Centre.

Senanayake, I. C., Bhat, J. D., Cheewangkoon, R., and Xie, N. (2020a). Bambusicolous Arthrinium species in guangdong province. China. Front. Microbiol. 11:602773. doi: 10.3389/fmicb.2020.602773

Senanayake, I. C., Maharachchikumbura, S. S., Hyde, K. D., Bhat, J. D., Jones, E. G., McKenzie, E. H., et al. (2015). Towards unraveling relationships in Xylariomycetidae (Sordariomycetes). Fungal Divers. 73, 73-144. doi: 10.1007/ s13225-015-0340-y

Senanayake, I. C., Rathnayake, A. R., Marasinghe, D. S., Calabon, M. S., Gentekaki, E., Lee, H. B., et al. (2020b). Morphological approaches in studying fungi: collection, examination, isolation, sporulation and preservation. Mycosphere 11, 2678-2754. doi: 10.5943/mycosphere/11/1/20

Sharma, R., Kulkarni, G., Sonawane, M. S., and Shouche, Y. S. (2014). A new endophytic species of Arthrinium (Apiosporaceae) from Jatropha podagrica. Mycoscience 55, 118-123. doi: 10.1016/j.myc.2013.06.004

Silvestro, D., and Michalak, I. (2012). raxmlGUI: a graphical front-end for RAxML. Org. Divers. Evol. 12, 335-337. doi: 10.1007/s13127-011-0056-0

Swofford, D. L. (2002). PAUP*: Phylogenetic Analysis Using Parsimony (*and Other Methods). Version 4. Sunderland, MA: Sinauer Associates.

Tang, X., Goonasekara, I. D., Jayawardena, R. S., Jiang, H. B., Li, J. F., Hyde, K. D., et al. (2020). Arthrinium bambusicola (Fungi, Sordariomycetes), a new species from Schizostachyum brachycladum in northern Thailand. Biodivers. Data J. 8:e58755. doi: 10.3897/BDJ.8.e58755

Vilgalys, R., and Hester, M. (1990). Rapid genetic identification and mapping of enzymatically amplified ribosomal DNA from several Cryptococcus species. J. Bacteriol. 172, 4238-4246. doi: 10.1128/jb.172.8.4238-4246. 1990

Wang, M., Tan, X. M., Liu, F., and Cai, L. (2018). Eight new Arthrinium species from China. MycoKeys 34, 1-24. doi: 10.3897/mycokeys.34.24221 
Wijayawardene, N. N., Hyde, K. D., Rajeshkumar, K. C., Hawksworth, D. L., Madrid, H., Kirk, P. M., et al. (2017). Notes for genera: ascomycota. Fungal Divers. 86, 1-594. doi: 10.1007/s13225-017-0386-0

Wijesinghe, S. N., Wang, Y., Camporesi, E., Wanasinghe, D. N., Boonmee, S., and Hyde, K. D. (2020). A new genus of Bambusicolaceae (Pleosporales) on Corylus avellana (Fagales) from Italy. Biodivers. Data J. 8:e55957. doi: 10.3897/BDJ.8. e55957

Yan, H., Jiang, N., Liang, L. Y., Yang, Q., and Tian, C. M. (2019). Arthrinium trachycarpum sp. nov. from Trachycarpus fortunei in China. Phytotaxa 400, 203-210. doi: 10.11646/phytotaxa.400.3.7

Yang, C. L., Xu, X. L., Dong, W., Wanasinghe, D. N., Liu, Y. G., and Hyde, K. D. (2019). Introducing Arthrinium phyllostachium sp. nov. (Apiosporaceae, Xylariales) on Phyllostachys heteroclada from Sichuan Province, China. Phytotaxa 406, 091-110. doi: 10.1127/nova_hedwigia/2019/ 0526

Zhang, J. F., Liu, J. K., Hyde, K. D., Chen, Y. Y., Liu, Y. X., and Liu, Z. Y. (2017). Two new species of Dyfrolomyces (Dyfrolomycetaceae, Dothideomycetes) from karst landforms. Phytotaxa 313:267. doi: 10.11646/phytotaxa. 313.3.4

Zhang, J. F., Liu, J. K., Jeewon, R., Wanasinghe, D. N., and Liu, Z. Y. (2019). Fungi from Asian Karst formations III. Molecular and morphological characterization reveal new taxa in Phaeosphaeriaceae. Mycosphere 10, 202-220. doi: 10.5943/ mycosphere/10/1/3

Zhao, Y. M., Deng, C. R., and Chen, X. (1990). Arthrinium phaeospermum causing dermatomycosis, a new record of China. Acta Mycol. Sin. 9, 232-235.

Zhao, Y. Z., Zhang, Z. F., Cai, L., Peng, W. J., and Liu, F. (2018). Four new filamentous fungal species from newly-collected and hivestored bee pollen. Mycosphere 9, 1089-1116. doi: 10.5943/mycosphere/9/6/3

Zhaxybayeva, O., and Gogarten, J. P. (2002). Bootstrap, Bayesian probability and maximum likelihood mapping: exploring new tools for comparative genome analyses. BMC Genom. 3:4. doi: 10.1186/1471-2164-3-4

Conflict of Interest: The authors declare that the research was conducted in the absence of any commercial or financial relationships that could be construed as a potential conflict of interest.

Copyright (c) 2021 Feng, Liu, Lin, Chen, Xiang and Liu. This is an open-access article distributed under the terms of the Creative Commons Attribution License (CC BY). The use, distribution or reproduction in other forums is permitted, provided the original author(s) and the copyright owner(s) are credited and that the original publication in this journal is cited, in accordance with accepted academic practice. No use, distribution or reproduction is permitted which does not comply with these terms. 